NBER WORKING PAPER SERIES

\title{
THE HISTORICAL ORIGINS OF U.S. EXCHANGE MARKET INTERVENTION POLICY
}

Michael D. Bordo

Owen Humpage

Anna J. Schwartz

Working Paper 12662

http://www.nber.org/papers/w12662

\author{
NATIONAL BUREAU OF ECONOMIC RESEARCH \\ 1050 Massachusetts Avenue \\ Cambridge, MA 02138 \\ November 2006
}

Paper prepared for the Conference "Exchange Rate Intervention: Theory and Evidence" Cambridge University, September 7-8, 2006. This article is based on research underlying a forthcoming monograph on U.S. Exchange Market Intervention by the authors. For helpful comments on an earlier draft of this paper we thank Paul DeGrauwe and Charles Goodhart. The views expressed herein are those of the author(s) and do not necessarily reflect the views of the National Bureau of Economic Research.

(C) 2006 by Michael D. Bordo, Owen Humpage, and Anna J. Schwartz. All rights reserved. Short sections of text, not to exceed two paragraphs, may be quoted without explicit permission provided that full credit, including $\odot$ notice, is given to the source. 
The Historical Origins of U.S. Exchange Market Intervention Policy

Michael D. Bordo, Owen Humpage, and Anna J. Schwartz

NBER Working Paper No. 12662

November 2006

JEL No. E42,N10

\begin{abstract}
$\underline{\text { ABSTRACT }}$
The present set of arrangements for U.S. exchange market intervention policy was largely developed after 1961 during the Bretton Woods era. However, that set had important historical precedents. In this paper we examine precedents to current arrangements, focusing on three historical eras: pre-1934 operations; the Exchange Stabilization Fund operations beginning in 1934; and the Bretton Woods era. We describe operations by the Second Bank of the United States in the pre-Civil War period and then operations by the U.S. Treasury in the post-Civil War period. After establishment of the Federal Reserve in 1914, the New York Fed engaged in isolated exchange market policies in the 1920s and 1930s, first under the direction of the Governor Benjamin Strong until his death in 1928, thereafter, under the direction of his successor, George Harrison. We then examine operations of the Exchange Stabilization Fund that the Gold Reserve Act of 1934 created as a Treasury Department agency. We exploit unique unpublished sources to analyze its dealings with the Banque de France and the Bank of England before and after the Tripartite Agreement. Finally, based on a unique data set of all U.S. Treasury and Federal Reserve foreign-exchange transactions, we discuss U.S. efforts from 1961 through 1972 to defend the dollar's parity under the Bretton Woods system.
\end{abstract}

Michael D. Bordo

Faculty of Economics

Cambridge University

Austin Robinson Building

Siegwick Avenue

Cambridge

ENGLAND CD3, 9DD

and NBER

bordo@econ.rutgers.edu

Owen Humpage

Federal Reserve Bank of Cleveland

P.O. Box 6387

Cleveland, $\mathrm{OH}$ 44101-1387

owen.f.humpage@clev.frb.org
Anna J. Schwartz

NBER

365 Fifth Ave, 5th Floor

New York, NY 10016-4309

and NBER

aschwartz@gc.cuny.edu 


\section{Introduction}

The present set of arrangements for U.S. exchange market intervention policy was largely developed after 1961 during the Bretton Woods era. However that set had important historical precedents. In this paper we examine the precedents to current arrangements focusing on three historical eras: pre 1934 operations; the Exchange Stabilization Fund operations beginning in 1934; the Bretton Woods era from 1961 to 1972 .

The exchange market policies followed before 1934 were not quite the same as modern exchange market intervention, but we believe that an understanding of the historical evolution of current arrangements can yield important insights for modern practices.

Modern exchange market intervention involves operations to influence the exchange rate independent of the other instruments of monetary policy. This has been interpreted during some episodes as pertaining to the level of the exchange rates and in other episodes to its volatility. The techniques used include direct purchases and sales of foreign currencies (both spot and forward) as well as swaps (a simultaneous spot and forward transaction). In addition, most interventions today are sterilized (accompanied by offsetting open market operations in domestic assets).

Exchange market policy before 1934 operated within the environment of the gold standard. Policies developed included: gold policy - policies to influence the position of the gold points; monetary policy actions to influence the market exchange rate and direct antecedents to modern exchange market operations. We describe in section 2 the operations by the Second Bank of the United States in the preCivil War period and then operations by the U.S. Treasury in the post-Civil War period. After establishment of the Federal Reserve in 1914, the New York Fed under the direction of the Governor Benjamin Strong until his death in 1928 engaged in isolated exchange market operations in the 1920s. Many of the policies followed then and subsequently were developed by the Bank of England and other European central banks during the classical gold standard and interwar gold exchange standard. 
We then focus on the operations of the Exchange Stabilization Fund founded in 1934, in section 3. We exploit unique unpublished sources to analyze the Treasury's dealings with the Banque de France and the Bank of England and other central banks before and after the Tripartite Agreement. Intervention involved purchase and sales of gold as well as of foreign currencies, aimed at minimizing exchange rate fluctuations. The focus was not on underlying misalignment of exchange rates.

Finally in section 4, based on a unique data set consisting of all U.S. Treasury and Federal Reserve foreign-exchange transactions, we discuss U.S. efforts from 1961 through 1972 to defend the dollar's parity within the Bretton Woods system. We describe specific types of transactions that U.S. monetary authorities undertook, focusing on Federal Reserve swap transactions and on U.S. Treasury mechanisms for backing up the System's swaps. The record shows that these operations were generally successful in forestalling U.S. gold losses and in raising the costs of speculative attacks. Ultimately, however, these operations enabled U.S. monetary authorities to avoid fundamental adjustments and in so doing, only delayed and possibly worsened Bretton Woods' ultimate collapse.

Section 5 concludes with a discussion of the legacy of the past for recent exchange market intervention policy. Today's environment of managed floating is very different from the gold-based pegged exchange rate regimes of the past. The object of policy is no longer to influence gold points or to preserve the peg. It is to create orderly markets or possibly to influence the level of the exchange rate, yet many of the technologies developed in the earlier era have been adjusted for this purpose. Intervention in the past decade has been a common practice of emerging market countries and regionally among Asian countries. Judging by its absence in recent years intervention has lost its appeal to policymakers in the U.S. and the E.U.

\section{Exchange Market Policy in the United States 1825-1933: Antecedents and Precedents}

\subsection{Introduction}

Exchange market operations had antecedents in U.S. history going back at least to the first decade of the nineteenth century and considerable precedents in Europe during the classical gold standard era from 1870 to 1913 and in the gold exchange standard from 1925 to 1933. 
The primary objective of exchange market policy then was to preserve adherence to the gold standard (i.e., to maintain the fixed gold parity by influencing gold flows.) Three principal approaches were used: policies to influence the position of the gold export and import points, such as restrictions on the location of offices where, and when, domestic fiduciary currency could be exchanged for gold; monetary policy actions (changes in discount rates and open market operations) targeted to influence the market exchange rate by altering interest rates so as to affect expenditure or to influence capital movement; direct antecedents to modern exchange market operations such as the purchase and sale of foreign exchange.

\subsection{Before the Civil War}

The U.S. in the first half of the nineteenth century could be characterized as a small open economy on a fixed exchange rate, the international specie standard. Most of its international trade was with England and involved staple exports of cotton and tobacco from the South and imports by the North of manufactured goods and commodities. Although the U.S. monetary standard was bimetallic, international transactions were undertaken largely in gold, which sold at a premium. Most payments were settled in the form of sterling bills drawn by merchant banks and other financial institutions in England.

The first use of official exchange market policy may have been carried out by the Second Bank of the United States, established in 1816, under its President Nicholas Biddle. The Bank began operations in foreign exchange in 1825. The original purpose for these operations was to offset seasonal fluctuations in the prices of sterling bills and to arbitrage bills of exchange rates between regions. Because of its size, extensive branch networks and its connection and line of credit of $£ 250$ million with Barings, the leading British merchant bank, the Second Bank quickly dominated the market for sterling bills.

Fritz Redlich (1951), a leading authority, claimed that Biddle engaged in deliberate exchange market intervention action: "Biddle entered the field of foreign exchange in order to protect the currency from foreign influences and to counteract possible disturbances of business" (p. 131). The same claim is made by Smith (1953), Hammond (1955), Myers (1970, p.88) and most recently by Officer (1992), who states, 
"Biddle was concerned whenever the exchange rate went beyond the gold-point spread...In such circumstances he would take steps to return the exchange rate to within the spread either through direct exchange transactions or through GTF/GPA (gold-effected transfer of funds/gold point arbitrage)" (p.204),

Yet we could find no actual empirical evidence of such operations. ${ }^{2}$ However, Smith's (1953, Chart V), shows an inverse relationship between the sterling exchange rate (60-day bills on London) and the foreign position of the Second Bank. According to Smith,

"Up to 1836, the Bank built up its foreign balances in the periods when foreign exchange rates were low and went into debt when the rates were high, a process not only stabilizing in its effects, but profitable to the banks" (Smith 1953, p.46),

thereby stabilizing the exchange rate.

\subsection{The Post-Civil War Period}

In the post-Civil War period, in two episodes, the U.S. Treasury was involved in exchange market operations. The first was a rescue operation of the U.S. Treasury arranged by a private consortium headed by J.P. Morgan and August Belmont in 1895, at the apex of the struggle over free silver. A U.S. budget deficit after 1890 and the issue of legal tender Treasury Notes of 1890, redeemable in coin, that the Sherman Silver Purchase Act of 1890 mandated, created uncertainty about the convertibility of the U.S. dollar, despite the repeal of the Sherman Act in 1893. To finance the deficit, the Treasury ran down its stock of gold and legal tenders. In January 1895, a run on gold in exchange for legal tenders reduced the reserve to $\$ 45$ million.

In February, the Treasury secretary contracted with the Belmont-Morgan banking syndicate, to market a $4 \%$ bond issue, and provide the Treasury with a 6-month short-term interest-free gold credit line to restore the gold reserve. One half of the 3.5 million ounces of gold delivered was to be shipped from Europe at a rate not exceeding 300,000 ounces a month. The syndicate agreed to protect the Treasury against gold withdrawals paid out to redeem legal tenders or sold to obtain exchange. It delivered an additional \$25 million in gold in exchange for legal tenders, and borrowed exchange in London to sell in

\footnotetext{
${ }^{2}$ In the fall of 1837, after the Second Bank of the United States lost its federal charter, Biddle now head of the United States Bank of Pennsylvania, cornered the cotton market for the purpose of both reviving it and reducing the
} 
New York, effectively controlling the exchange market. The syndicate marketed the bonds for a total of $\$ 68.8$ million. During the five months after the contract was signed, no gold was withdrawn from the Treasury.

The second episode was an attempt in March 1906 by Treasury Secretary Shaw to raise the gold import point. To reduce pressure on the New York commercial banks, Secretary Shaw reduced the interest cost on gold imports and thereby lowered the gold import point by a few cents. According to Beckhart et al. (1932 vol. IV), he "allowed the New York banks to count gold in transit as part of their reserves". As we will consider below, Shaw was following the type of gold policies which had already been perfected by the Bank of England and other European central banks. Although there had been pressure on the Treasury to support sterling exchange in New York on earlier occasions (Beckhart et al. 1932, vol. IV, p.190), such as during the panic of 1873, these seem to be the only episodes when such operations were actually conducted.

\subsection{World War I and the Establishment of the Federal Reserve}

The Federal Reserve Act was passed in 1913, and the system began operations in 1914. The Federal Reserve Board was given the power

"to permit the acceptance of drafts drawn to create dollar exchange, to pass upon applications for and to regulate foreign trade banks and foreign branches of member banks and to regulate direct dealings by the Federal Reserve banks in gold, cable transfers and bills of exchange" (Beckhart et al. 1932, vol. IV, p.216).

With U.S. entry into World War I in April 1917, the monetary authorities began active involvement in stabilizing exchange rates. Credits were given to the allies to help peg their currencies, and arrangements were made so that the allies could pay for exports directly (Beckhart et al.1932, vol. IV, p.238).

Because U.S. exports to neutral countries had been diverted to the Allies ,gold losses hampered the monetary expansion policies of the U.S. authorities. The gold drain led to the imposition of an embargo on gold exports in June 1917, and the institution of strict exchange controls beginning in 
February 1918. The controls which were administered by the Federal Reserve Board required licenses for anyone seeking access to foreign exchange. A division of foreign exchange was set up with offices in Washington and New York (Beckhart et al. 1932, p.243).

In September 1918, to address the continuing discount on the dollar in neutral countries, the Secretary of the Treasury negotiated special credit arrangements to obtain a supply of foreign exchange from these countries. Finally, in September 1918, the Treasury was given the power to cooperate with other countries to stabilize their currencies (Beckhart et al. 1932, p.248).

The panoply of controls over the foreign exchange markets and stabilization credits to the Allies, which were terminated between December 1918 and May 1920, established the machinery for future exchange market operations by the U.S. monetary authorities.

\subsection{U.S. Exchange Market Policies 1919-1931}

After the war, Benjamin Strong, Governor of the Federal Reserve Bank of New York, emerged as the dominant player in the development of U.S. monetary policy and international arrangements. In 1916 he negotiated an agreement with the Bank of England (and later with the Banque de France). Under the agreement, the New York Fed opened an account with the Bank of England in earmarked gold and the Bank of England purchased prime sterling bills for the Fed.

The heyday of Federal Reserve international policies and the use of various types of exchange market operations began in 1924 when the New York Fed adopted policies designed to help Britain restore convertibility of sterling at the pre-war parity of $\$ 4.86$. Strong, after his first visit in 1916 , had developed a good rapport with Montagu Norman, governor of the Bank of England. Both had similar views on the need to restore and maintain the gold standard worldwide, and in pursuing cooperative policies. They also believed that the stabilization of sterling would be the catalyst for other countries to restore convertibility.

By 1924 conditions became favorable for resumption of sterling at its prewar parity. A cooperative strategy to reduce the price gap between the US and the UK (calculated by Strong at 10\%), 
by lowering U.S. interest rates and providing credits to the Bank of England, was followed. In May 1924, the New York Fed established a \$200 million 2-year line of credit for the Bank of England in gold or dollars with interest to be charged only on amounts actually drawn, with the rate set at $1 \%$ above the New York Fed's discount rate on 90-day bills.

In addition, in the spring of 1924 the Federal Reserve began easing monetary policy by reducing its discount rate from $4 \frac{1}{2} \%$ to $3 \%$ to counter a recession which had begun in the fall of 1923 . At the same time, the Bank of England kept interest rates firm at 4\% despite high unemployment. The coordinated policy was considered a success, sterling rose towards parity from May 1924 to April 1925, British gold reserves increased and the price differential between the two countries dropped to within $2 \frac{1}{2}$ $\%$ of parity, allowing Britain to resume convertibility in April 1925 (Clarke 1967).

Once sterling was stabilized, the New York Fed participated in a number of stabilization packages to restore convertibility to the Belgian franc in 1926, the French franc in 1926, the Italian lira in 1927 and a number of lesser currencies in the rest of the decade. All of these packages involved lines of credit supplied by the Federal Reserve as well as private credits to the governments (Chandler 1958).

Once the gold standard was re-instated, sterling was faced with ongoing pressures; it had, it turned out, returned to parity at a significantly overvalued rate. Strong was instrumental in persuading the French and the Germans to pursue policies which would ease the gold drain in Britain and in employing the Federal Reserve facilitate some of these operations. One example of Strong's efforts was the repayment by the Banque de France in April 1927 of a 1923 debt to the Bank of England; the Banque also "recovered more than $\$ 80$ million of gold formally pledged as security for the loan and then sold the gold to Irving Trust Company in New York ... Strong then purchased $\$ 60$ million and held it under earmark at the Bank of England" (Chandler 1958, p.375).

The policy prevented

"a rise in the gold reserve of the New York Bank, avoided the psychological effects that might have arisen from a large gold shipment, and provided Strong with a gold balance in London that later proved useful" (Ibid., p.375).

Later in June

"when Moreau [ President of the Banque de France] was taking gold from London, Strong sold him the $\$ 60$ million of earmarked gold thereby easing the drain from the Bank of England. He 
also purchased some sterling bills to ease the British position and to prevent gold flows to the United States" (Ibid., p.378).

The most important episode of coordinated exchange market policy then took place, beginning in July 1927, when Strong invited Norman, Moreau and Schacht (President of the Reichsbank) to a conference at the Long Island estate of Ogden Mills, Under Secretary of the Treasury. The conference led to a number of significant policy actions. First, the Federal Reserve engaged in expansionary open market purchases from June to November of about \$200 million and lowered the discount rate from 4 to $3 \frac{1 / 2}{\%}$ from July $29^{\text {th }}$ to mid-September. Second, both the Banque de France and the Reichsbank shifted their gold purchases from London to New York. Third, the Reichsbank also reduced its discount rate (Chandler 1958, pp.275-277, Clarke 1967). These policy moves were successful in easing the U.S. recession and temporarily taking pressure off sterling.

In 1928 - 29, the strains in the international monetary system continued to build up. In response to the Wall Street stock market boom the Federal Reserve began tightening monetary policy, conducting open market sales and raising the discount rate from $3 \frac{1}{2}$ to $4 \frac{1}{2} \%$, attracting capital flows from Europe. Additional strain on sterling came from the Banque de France which, after the de jure stabilization of the franc on June 25, 1928, began a policy of absorbing gold inflows and converting its foreign exchange reserves into gold (Clarke 1967). Attempts at further cooperation came to naught until the summer of 1929, when Harrison at the New York Fed (Strong's successor) engaged in market operations to support sterling. The New York Fed purchased \$41 million in sterling in August and September after the Fed had raised its discount rate from $5 \%$ to $6 \%$.

A recession in the U.S. in August 1929, exacerbated by the Wall Street crash in October, marked the start of the Great Depression. It spread from the U.S. to the rest of the world via the fixed exchange rate links of the gold standard. In 1930 - 31, the Federal Reserve was involved in a number of exchange market operations initially to help shore up and later save the British pound as well as the Austrian schilling and the German mark. In September 1930, to prevent a gold drain from London to New York, Norman asked Harrison to help support sterling. Between October 14 and October 30 the New York Fed 
acquired $£ 4.7$ million. Then in November, New York bought another $£ 2.5$ million. The operation was deemed successful (Clarke 1967, p.175).

U.S. exchange market operations occurred again during the 1931 crisis. The collapse of the Credit Anstalt Bank in May 1931 led to a banking crisis, a bailout by the Austrian National Bank and a speculative attack on the schilling. A coordinated rescue package of $\$ 14$ million (of which the U.S. share was $\$ 3$ million) that the Bank of International Settlements organized, was too little and too late to stem the crisis. The crisis spread to Germany. A speculative attack on the Reichsbank's reserves threatened to breach its statutory gold reserve requirements in June. The Reichsbank then sought and obtained an international loan of \$100 million (\$25 million each from the Bank of England, Banque de France, Federal Reserve Bank of New York and the BIS) on June 25. The loan proved insufficient to defeat the speculative attack. A second loan request by Hans Luther, the President of the Reichsbank, for $\$ 1$ billion foundered in the face of opposition by both the Banque de France and the Federal Reserve. The external drain was finally halted by the announcement on July 20 of a standstill agreement and the imposition of exchange controls (Bordo and Schwartz 1999).

The crisis then spread to Great Britain. A speculative attack on the Bank of England's gold reserves in the late summer of 1931 triggered by the freezing of British deposits and assets in Austria and Germany but ultimately reflecting a seriously deteriorating fiscal problem. In the final week of July 1931, the Bank of England obtained matching credits for $\$ 25$ million from the Federal Reserve Bank of New York and the Banque de France. The amount was inadequate to halt the run. Further loans to Britain of \$200 million each from a syndicate formed by J.P. Morgan with the help of Harrison in New York and a syndicate in Paris also proved inadequate.

The Federal Reserve was heavily involved in various types of exchange market policies from 1924 to 1931 . These interventions and credits were all motivated by the desire to strengthen and protect the currencies of other countries, and in particular sterling. The object was to preserve the gold (exchange) standard, which, it was believed, was the key pillar of monetary stability. Until 1931, many of 
these operations were successful in achieving their aims. Ultimately the gold exchange standard collapsed, but whether it could have survived absent the shock of the Great Depression, is still arguable.

\subsection{European Precedents: The Classical Gold Standard 1870-1914}

Many of the techniques later used by the Federal Reserve were first developed by the Europeans.

\subsubsection{Gold Policy}

The Bank of England and the other principal central banks engaged in 'gold policy' or used 'gold devices' to alter the gold export and import points. These policies complemented discount rate policy and sometimes served as a substitute. The policies followed by virtually all central banks included altering the prices for gold bars or foreign gold coin; granting interest free advances to gold importers during periods of gold transit; only redeeming notes at head office; and placing physical impediments to the export of gold (Bloomfield 1959, 1963 , Sayers 1936).

\subsubsection{Foreign Exchange Market Intervention}

The Bank of England never used official purchases and sales of foreign exchange as a policy to keep the exchange rate within the gold points because it did not hold reserves other than gold. The Banque de France and the Reichsbank rarely used such operations. However, Bloomfield (1963) describes how other European central banks which held reserves in both gold and foreign exchange (sterling, francs and reichsmarks) as well as the monetary authorities of the colonies operating on a gold exchange standard did engage in such policies. According to Bloomfield (1963, p.21), many European central banks including those of Belgium, Holland, Sweden, Switzerland and Russia engaged in exchange market intervention to smooth seasonal and erratic fluctuations in the exchange rate as well as to arrest movements to the gold export point.

Two countries that extensively relied on exchange market intervention before 1914 were Finland and Austria-Hungary. In the case of Finland, after it adopted the gold standard in 1877, "the exchange rate 
was kept within the gold points exclusively by purchases and sales of foreign exchange by the Bank of Finland.” (Bloomfield 1963, p.23).

The Austro-Hungarian Bank from 1896 to 1914, after the empire adopted a gold currency in $1897^{3}$, was able to maintain parity between the crown and gold by its foreign exchange policy.

Bloomfield (1963, p.24) describes how the Bank would sell foreign exchange just before the theoretical gold export point was reached and buy foreign exchange just before reaching the gold import point. The Austro-Hungarian Bank was also an early pioneer in the use of official operations in the forward market. ${ }^{4}$

Thus exchange rate policy, both gold policy and exchange market interventions were well developed before 1914 in Europe. These policies were further developed in the interwar gold exchange standard.

\subsubsection{Exchange Market Operations 1926 - 31 .}

The European central banks and especially the Bank of England engaged in extensive exchange market operations once the gold standard was fully restored in 1926. The Bank of England engaged in gold policies similar to those before 1914 and it also operated directly on the exchange rate. ${ }^{5}$

Active policy began after the July 1927 Long Island meeting between Norman, Strong and other governors. The object of the policy was to divert gold withdrawals by the Banque de France and other continental central banks away from London and to New York, despite the fact that gold prices were as a rule cheaper in London. ${ }^{6}$ The Bank began paying higher than its $77 \mathrm{~s} 9 \mathrm{~d}$ (the standard ounce of gold) buying price in the summer of 1928 and followed similar (pre-1914) policies as well as moral suasion until September 1931 (Moggridge 1972, p.173). Einzig (1931) estimated that these measures could affect the London-New York gold export point by as much as $1 \%$.

\footnotetext{
${ }^{3}$ Although Austria-Hungary adopted a gold currency after decades on a paper standard, it never obligated the banks to redeem its notes in terms of gold. Also see Yeager (1976)

${ }^{4}$ According to Flandreau and Komlos (2002), the Austrian National Bank operated as if it were bound by a target zone, as Bordo and MacDonald (2005) claim was the case for the core countries.

${ }^{5}$ Although we focus mainly on the Bank of England, the Banque de France also pursued in extensive exchange market policies including gold policy, spot and forward market interventions and swaps. See (Clarke 1967).

${ }^{6}$ Reflecting higher eastbound Atlantic freight rates and higher interest costs of shipping gold from New York (Moggridge 1972, p.171).
} 
The Bank of England and the other central banks also pursued vigorous exchange market interventions in the interwar period. The Bank operated directly in the foreign exchange market, through a number of correspondent banks, and through dealings with other central banks. The Bank's operations until 1931 (and subsequently) were done in the strictest secrecy and the transactions were buried under the item Other Securities in the Banking Department's balance sheet. The Bank feared that, if the public knew it held hidden reserves as large as its published reserves, it would have great difficulty in pursuing its deflationary policies. ${ }^{7}$ The Bank also automatically sterilized its operations by compensating security purchases or sales. According to Moggridge (1972, p.185), this policy of automatic complete offsetting represented an innovation.

The most active period of intervention occurred from September 1926 to September 1929, when, to prevent gold exports, the Bank sold dollars in the open market spot for 10 months during which the sterling dollar rate was below the average gold export point (Moggridge 1972, p.185). It also, on occasion (March 1928 and in 1930), sold foreign exchange to reduce funds in the domestic market (a form of monetary policy) (Moggridge 1972, p.186), and it used its foreign exchange holdings to shift asset conversions to other central banks (Moggridge 1972, p.188).

As discussed in section 2.4 above, the Bank of England in its perennial defense of sterling was also aided by the New York Fed, the Banque de France and other central banks. The Fed purchased sterling on three occasions between June 1927 and December 1930 and the Banque de France supported sterling in late 1930 and 1931

Finally, the Bank engaged in massive interventions in the 1931 sterling crisis. Between July and September, the Bank sold \$381 million dollars spot and \$125 million forward as well as £53 million in francs; 83\% of its reserve losses resulted from both operations (Moggridge 1972).

Despite the disaster at the end, the Bank's exchange market policies enabled it to raise its gold reserves in the majority of quarters from 1926 to 1931 . The reserve accumulation also allowed the Bank to follow an easier policy than otherwise, to violate the gold points on numerous occasions and to insulate

\footnotetext{
${ }^{7}$ It kept its operations secret by operating through the Anglo-International Bank and through numbered accounts at the New York Fed (Moggridge 1972, p.184).
} 
the British economy from external shocks (Moggridge 1972, pp.196-97). A key problem with its successful secret intervention is that the Bank's international reserves did not signal the good state of the British economy. This in turn prevented the normal price-specie flow adjustment mechanism of the gold standard from working, thus creating the conditions for a later adjustment following a crisis.

\subsection{Antecedents and Precedents: The Lessons}

In 1934 when the Exchange Stabilization Fund was established by the U.S., and later in 1962 when the Federal Reserve became its partner in interventions, a wealth of techniques they could draw on was available to them. The Treasury and Fed had used them in wartime and interwar operations. The Treasury and Fed as well could look back to the pre-1914 experiences of the Second Bank. U.S. policies and institutions may also have been influenced by those developed by the Bank of England and other European central banks.

Yet the legacy for future U.S. policy of Federal Reserve exchange market intervention in the 1920s was limited at best. First, it was used only sporadically and then only at the behest of the Bank of England. Second, the international monetary policies followed by Benjamin Strong and the New York Federal Reserve to help restore and preserve the international gold standard and especially the actions taken to alleviate threats to Britain's continued adherence to gold in 1927 were later stigmatized as key causes of the stock market crash in October 1929 and the Great Depression. Adolph Miller, of the Federal Reserve Board (Miller 1935) condemned Strong's expansionary policies in 1927 as the cause of the stock market boom that the Fed believed it had to defuse to prevent inflation.

A further case against Strong made by H. Parker Willis of Columbia University and Senator Carter Glass was that he had violated the intent of the Federal Reserve Act by acting on behalf of the New York Federal Reserve Bank alone and not on behalf of the system in conducting in international monetary policy (Willis and Chapman 1934, p.83).

Thus in the face of this withering attack, it is likely that the Federal Reserve had little incentive to pursue the type of international cooperation and exchange market policies associated with Benjamin Strong and the 1920s. When the Federal Reserve again began to intervene in the 1960s, it started with a 
clean slate. At the same time, the perception in the Roosevelt administration in 1933 that the crash and the depression were caused by inappropriate policies of the New York Fed, the greed of bankers, Wall Street, and finance capitalism in general, led to the shift in monetary policy authority from the Federal Reserve to the Treasury. International economic policy in the future and exchange market intervention in particular were to be conducted by the Exchange Stabilization Fund, as discussed below.

\section{The Exchange Stabilization Fund 1934 to $1961^{8}$}

\subsection{Introduction}

The Roosevelt administration took office in March 1933 with the express intention to permit the dollar to depreciate in terms of foreign currencies as a means of achieving a rise in domestic prices. To further this aim, it initiated a gold purchase program to increase both the number of ounces and the price per ounce of the U.S. gold stock. On 5 June by a joint resolution of Congress, so-called gold clauses in many government and private obligations, requiring either payment in gold or in a nominal amount of currency equal to the value of a specified weight of gold, were declared invalid in all public or private contracts, past or future. Lawsuits challenging the resolution roiled the foreign exchange value of the dollar until the Supreme Court ruled in its favor February 1935.

The gold purchase program went forward in September 1933, when the Treasury agreed to buy gold at an official gold price to be fixed daily. The period of a variable price of gold came to an end on 31 January 1934, when the President under the authority of the Gold Reserve Act, passed the day before,

\footnotetext{
${ }^{8}$ We rely on three unpublished sources for the details of intervention: (1) W.A. Brown, Jr., who was given access to ESF documents from 1934 to 1939, in 1942 wrote a 200-page study, indicating what needed to be checked, and leaving blank pages for charts. He did not resume work on the manuscript; (2) Indirect references to ESF operations, among a host of other topics, are available in the microfilm of documents that Treasury Secretary Henry Morgenthau, Jr., deposited in the FDR Library in Hyde Park, New York. The microfilm in 60 reels, covering the period 1934-45, includes transcripts of every telephone conversation Morgenthau had with Treasury representatives at U.S. Embassies abroad; every meeting with Treasury staff, representatives of other departments, visiting foreign officials; and of particular interest, telephone conversations with George Harrison, governor (later president) of the FRBNY, and with the manager of the foreign exchange desk at the Bank to whom the Secretary conveyed instructions regarding purchases and sales. We refer to these documents as the Morgenthau Papers. They are not Morgenthau's Diaries, the title the FDR Library assigns to the microfilm collection; (3) Selected documents from the Archives of the Bank of England.
} 
specified a fixed buying and selling price of \$35 an ounce for gold (formerly \$20.67), thereby devaluing the gold dollar to 59.06 per cent of its former weight.

On 30 January 1934, the Gold Reserve Act transferred to the United States title to all gold of the Federal Reserve System. The Treasury was also the recipient of gold coin, gold bullion and gold certificates that individuals, partnerships and corporations were required by Executive Order to deliver.

In addition, the Act established the Exchange Stabilization Fund (ESF). A motive for establishing the ESF was the U.S. suspicion that the Exchange Equalization Account (EEA) that the British created in 1932 to control sterling exchange was intended to keep sterling from appreciating relative to the dollar. To make depreciation of the dollar that devaluation had achieved effective, FDR concluded required establishment of a fund comparable to the one the British had.

Section 10 of the Act, provided that $\$ 2$ billion of the $\$ 2.8$ billion devaluation profit be deposited with the Treasurer of the United States in a stabilization fund under the exclusive control of the Secretary of the Treasury, with the approval of the President, whose decisions shall be final and not subject to review by any other officer of the United States. The fund was authorized to deal in gold and foreign exchange and such other instruments of credit and securities as he may deem necessary for the purpose of stabilizing the exchange value of the dollar.

On 27 April 1934 the ESF was formally set up. The ESF first intervened in the foreign exchange market on 5 September, 1934. We know from the Treasury's announcement on 31 January 1934 that it would sell gold to foreign central banks whenever U.S. exchange rates with gold standard currencies reached the gold export point, that the Treasury was familiar with a crucial feature of the gold standard, as it existed either before sterling began to float against the dollar and other currencies in September 1931, or after the dollar was devalued - the gold export and import points that defined the range within which fixed exchange rates could fluctuate. It was the responsibility of a monetary authority in a gold standard regime to keep the level of exchange rates of their national currency within boundaries set by the fixed gold import and the fixed gold export points. 
In 1934 the only currencies with such fixed points were the French franc, the currencies of the gold bloc countries - the Netherlands, Belgium, Switzerland - and the U.S. dollar. Sterling, by contrast, had no mint parity from which to calculate import and export points. Transactions in both gold and foreign exchange kept a currency that was on the gold standard and one that floated within a given range. A floating currency's value oscillated between a high and a low value. Intervening within gold points or between high and low values of a floating currency used the same techniques. At the gold export point and at the peak floating rate value, the monetary authority bought gold to counter appreciation. At the gold import point and the low floating rate value, it sold gold, which it might have held as reserves, or borrowed. In addition to gold operations, another channel that was used to reduce fluctuations in the exchange value of a currency was the purchase and sale of that currency to bolster it or to rein in its value.

We now turn to some details of Treasury intervention, first in support of the French franc, then in a more adversarial role with respect to floating sterling. We cover the pre-Tripartite period and then the different arrangements that followed. ${ }^{9}$

\subsection{Dollar-Franc Rate Intervention Before the Tripartite Agreement}

In the second half of 1933, recovery was under way in the world economy, but France began to experience a deepening depression. Earlier it had been insulated against the worldwide economic decline by its massive gold reserves. Over the period 1933 to 1936 France experienced mounting reserve losses in the face of an increasingly overvalued franc. Ongoing political instability reflected the inability to deal with the deflationary pressure. In these years the ESF was involved in numerous operations to buoy up the franc.

Figure 1 illustrates some highlights of the behavior of the U.S. dollar-franc exchange rate from the start of Treasury-ESF intervention in September 1934 until the outbreak of war in 1939. The Tripartite period beginning September 1936 is distinguished. The dashed line tells the story of the relatively stable exchange rate of the franc in the pre-Tripartite years and its subsequent cascading loss of value. Intervention is depicted by franc purchases (dark gray bars) and sales (light gray bars) at monthly dates. 
Since gold transactions were important episodes of the intervention history, the figure gives only a partial account. Figure 3 gives some information on gold prices, net imports of gold to the U.S. and the increase in gold earmarked in Federal Reserve Banks on foreign account. The data do not identify the foreign owners of the earmarked gold.

Figure 1: U.S. Dollar - French Franc Exchange Rate

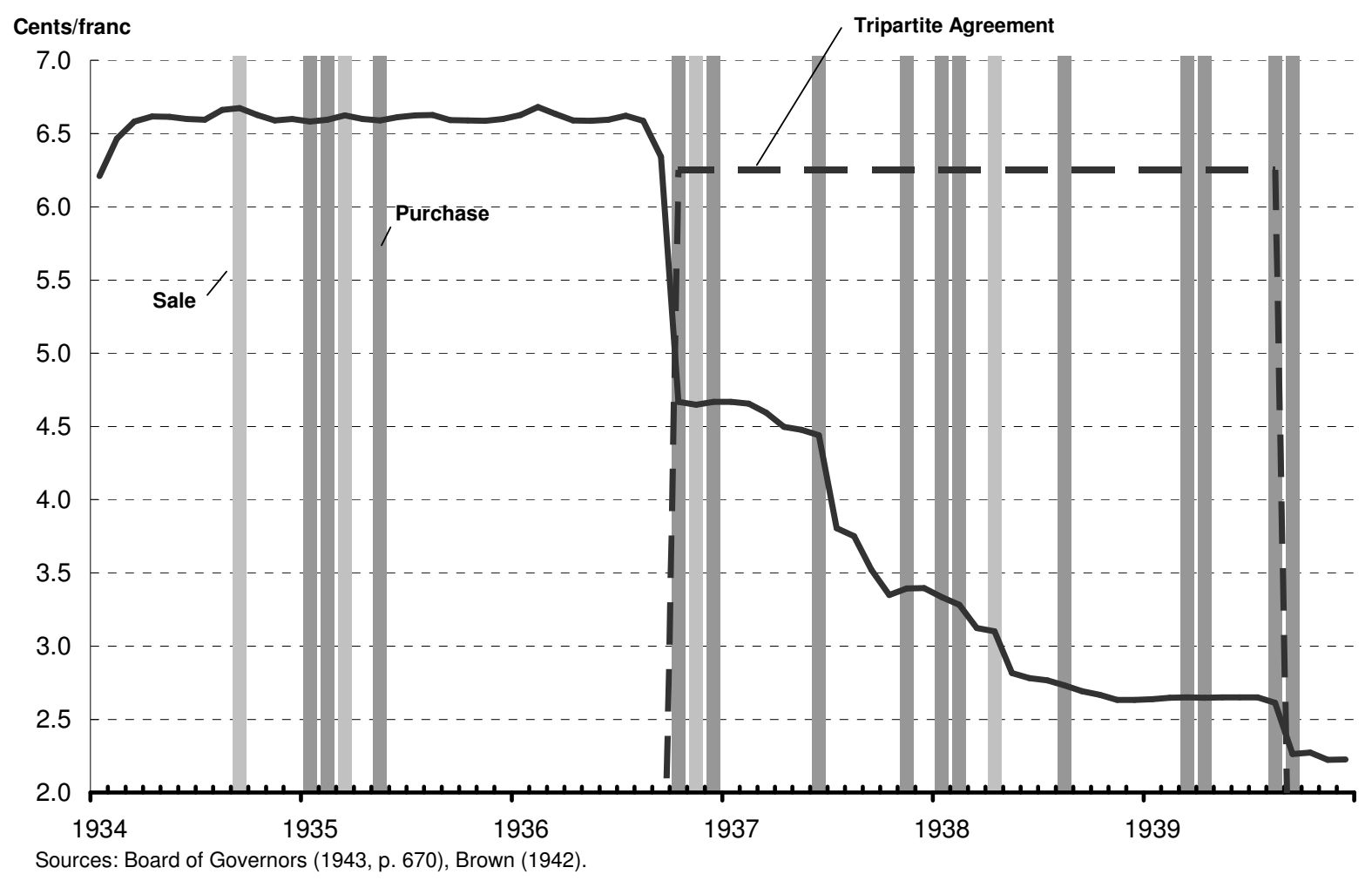

The first large-scale intervention by the ESF in the franc was on 5 September triggered by the strength of the franc relative to the dollar and sterling from mid-August on. Gold from the London market moved to Paris, not New York. The market believed that a further devaluation of the dollar was likely, or a substantial U.S. inflation, and that sterling depreciation would accompany the dollar's movement. Speculators sold dollars.

\footnotetext{
${ }^{9}$ In this paper we present some examples of intervention. For more detail including interventions in other currencies, see Bordo, Humpage and Schwartz (2006a).
} 
On 5 September, the ESF acquired 134.4 million spot francs by selling 140.0 million three months forward against spot. It sold 85.2 million of the spot plus 3.7 million three months forward. Guaranty Trust as the FRBNY agent executed these transactions, forcing the dollar-franc rate below the gold export point. It is possible that what might have occurred was a swap, whereby the ESF bought 134.4 million francs with dollars spot from the Banque de France, and entered into an agreement to sell them forward again to the Banque de France at a known exchange rate. The ESF then used the francs to intervene with the market, selling 85.2 million spot and 1.2 million forward. The Fund ended with a net uncovered forward position of \$6 million equivalent francs.

From 5 to 25 September it sold spot francs at a price above the dollar-franc parity but below the gold export point to Paris. The dollar strengthened in Paris during 22-28 September, and the ESF was able to buy spot francs at a profitable rate to cover its forward position. Brown (1942, p.50) credits the ESF with imposing a check on an outward movement of gold to Paris due to purely temporary causes, thus contributing to the stability of the dollar-franc rate. Shipments of gold in both directions were avoided and as a by-product the ESF had a profit of $\$ 335$ thousand.

A second example of intervention followed the French franc's weakness in May 1935 produced by political agitation for its devaluation, unsolved budget difficulties, and loss of gold by the Banque de France. The U.S. Treasury used the ESF to support the French franc in the following manner. It arranged for the FRBNY by telephone to buy up to $\$ 5$ million in gold to be earmarked at the Banque de France in the name of the FRBNY, guaranteed for export under all circumstances. Unlike other examples of earmarking guarantees, which were provided not only by the central bank but also by the government, in this case the French government guarantee was not required. The Banque de France was authorized to sell dollars for francs at 6.58 cents or better up to $\$ 5$ million. The sale of the dollars provided francs to the Banque de France, which was authorized to earmark the equivalent gold for the FRBNY.

On 24 May the FRBNY changed the form in which assistance was offered to the Banque de France. Two conditions were set. One required the Bank, if it sold dollars, to advance the franc equivalent value as of 25 May and convert the francs into gold to be earmarked in the FRBNY name on 25 May 
guaranteed free for export to the FRB by the first available steamer. The FRBNY, on receipt of cable advice of the amount of dollar sale and conversion of francs into gold earmarked in its name, would give the Bank credit on its books for the value of such dollars on 25 May.

The FRB also offered to buy up to $\$ 5$ million in gold earmarked at the Bank to be shipped to the U.S. Assay Office in New York by the first available direct steamer, settlement to be provided by the Treasury. On receipt of advice that the gold had been earmarked, the FRB would credit the Bank with dollars to be disposed of as it wished. The dollars this offer extended to the Bank enabled it to purchase francs at a rate of its choice. And it immediately accepted the offer.

The ESF then bought $\$ 5$ million in gold from the Bank. The offer was renewed and the ESF bought another $\$ 5$ million in gold. No improvement was registered in the exchange market. To halt gold losses, beginning 23 May the Banque de France raised the discount rate in steps from $2 \frac{1}{2}$ per cent until 28 May, when it raised the discount rate to 6 per cent. The ESF again came to the rescue. The FRBNY on 27 May offered to buy $\$ 25$ million in gold on 28 May on the same terms as earlier.

The renewal of the French financial crisis in June 1936 was marked by a drain of gold from the Banque de France to the U.S. Gold losses persisted through September. Popular discontent with deflation mounted, France finally had to confront the prospect of devaluation, which it had firmly rejected in the years since the franc's parity was established in 1928. It had come to believe that it was not the franc that was out of line but the dollar and sterling that were out of line with the franc. The reality could no longer be denied.

The chronic French financial problem was temporarily solved by the Tripartite Agreement, adopted on 25 September by the U.S., Britain and France to allow the French to devalue the franc with no retaliation by the others. On 26 September the government agreed to back suspension of the gold standard by the Banque de France.

\subsection{Dollar-Sterling Rate Intervention Before the Tripartite Agreement}


Britain's economic situation at the time the ESF began to intervene in sterling can be briefly described. By abandoning the gold standard in September 1931, it gained the flexibility to lower interest rates (because of fears of inflation, after a delay) in June 1932, expand high-powered money, and yet augment its reserves, with the result that its exports grew, unemployment declined, and national income rose in each year from 1933 to the outbreak of the war.

Figure 2 for the U.S. dollar -pound exchange rate matches figure 1 for the U.S. dollar franc exchange rate. The black line tracks the floating pound exchange rate. A declining trend of the pound's

Figure 2: U.S. Dollar-British Pound Exchange Rate

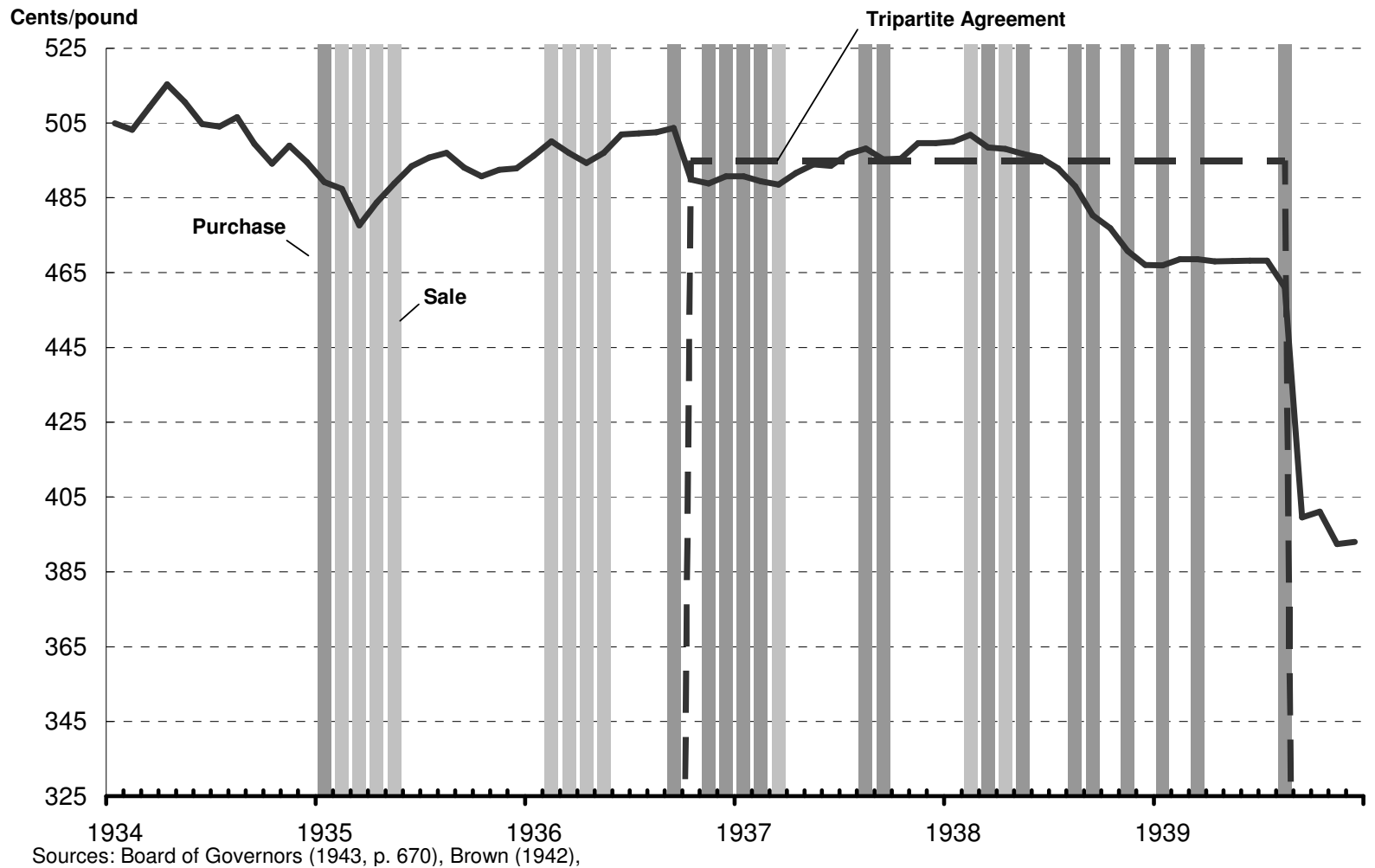


Figure 3: Gold Prices, Imports and Changes in Earmarks

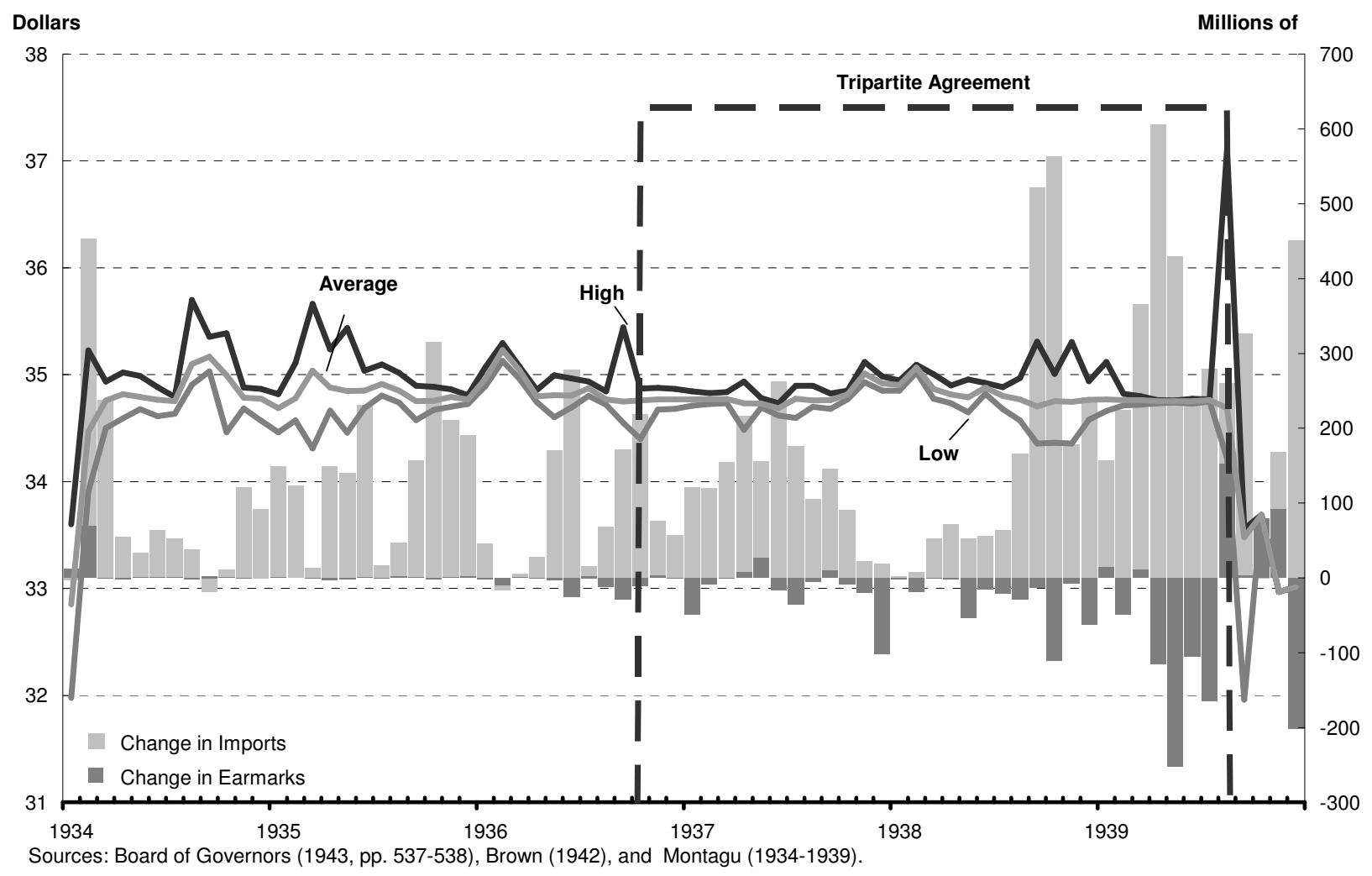

value sets in as the threat of war grows. ESF purchases of sterling are depicted by dark gray bars, sales by light gray bars at monthly dates. Gold transactions, an important part of ESF intervention in London and New York are omitted from the figure.

The U.S. was willing to buy and sell gold at a fixed price but only for currencies convertible into gold at a fixed price. The ESF in principle would not sell gold in London for which it would be paid in inconvertible sterling. It did not sell gold to the EEA from April 1934, when the ESF was established until October 1936, when agreement was reached among the Tripartite principals for reciprocity with respect to sales of gold to each other (Brown 1944, p.158). For that period in turn the EEA did not deal in dollar exchange. The Treasury, however, had no objection to buying gold either from the Bank of England or the London gold market. 
No regular channel of communication with respect to foreign exchange moves existed between the U.S. and Britain until the Tripartite arrangements. Informal contacts between the FRBNY and the Bank of England, however, were commonplace.

The price of gold in London was basically determined by the dollar-sterling rate and the fixed buying price for gold with which the Treasury operated. The influence on the London price of gold was transmitted indirectly through the stable franc-dollar rate that gold standard arrangements were responsible for (Brown 1944, p.147).

The EEA could not manage the sterling rate with operations in New York, but it could achieve its ends through operations in francs. To prevent appreciation of sterling, it would buy francs that it sold immediately for gold from the Banque de France. In the opposite case, if the EEA wanted to stem excessive sterling depreciation, it could sell gold to the Banque de France for francs to support sterling.

The Treasury was under no obligation to narrow the range of the fluctuations in the dollar-sterling exchange rate, an obligation it did have to support the parity of the dollar-franc exchange rate. Whenever the franc exchange rate rose to the gold export point, the Treasury would release gold to France or any other gold standard country under the same circumstances. Whenever the franc exchange rate fell to the gold import point, the Banque de France would release gold to the United States.

In practice, however, both the market and the Treasury treated the sterling rate just as they treated the franc rate. The franc exchange rate fluctuated between the 1 per cent spread between the fixed gold export point and the fixed gold import point. The dollar-sterling exchange rate fluctuated between a shifting high market value and a shifting low market value. Whenever sterling rose to a peak value, the market and the Treasury sold sterling. Gold would also move to London. Whenever sterling fell to low values, the Treasury bought sterling and gold in London. It was in the U.S. interest to keep sterling within its market boundaries.

An episode of intervention we document began on 15 January 1935, when the market was roiled by worry that the Supreme Court might rule that the abrogation of the gold clause was unconstitutional. Since both the franc and sterling were weak, the ESF bought francs in Paris and also bought 14,300 
ounces of gold in London at $\$ 34.60$ per ounce, and an additional 30,100 ounces at $\$ 35.65$ the next day. For the next ten days, sterling moved between $\$ 4.875$ and $\$ 4.882$, but on 24 January the ESF resumed buying gold in London. On 26 January, when the sterling rate fell to $\$ 4.86$, it bought sterling in New York at $\$ 4.8510$ and sold $\$ 5$ million for sterling in London on 28 January, despite the fact that sterling was not convertible. The sterling purchases were accompanied by further gold purchases in London, \$1.54 million during 15-21 January, \$9.95 million the following week, and \$1.683 million during 28 January-4 February.

During the three weeks that the ESF actively entered the exchange market, it spent \$21 million for gold in London, sold \$36 million for francs in Paris, and bought $\$ 14$ million in sterling. From 16 January to 18 February, the ESF support of sterling totaled $\$ 85.8$ million (Brown 1942, p.65). After the Supreme Court decision on 18 February upholding the abrogation of the gold clause, sterling strengthened, and the Fund sold \$2.81 million in New York at \$4.8842. An open position in sterling remained to be liquidated, but intervention was at an end.

The most significant development in the dollar-sterling relationship was the decision on 15 January 1935 of the Treasury to request the Bank of England to buy gold for it in London in amounts of ounces and at a price the Treasury stipulated. Once the request was granted, the arrangement to obtain gold for the Treasury with cooperation of the Bank of England persisted from 1935 until the Second World War.

The Treasury's objective in buying gold in London was not to accumulate gold there but to offer arbitrageurs in that market (who would sell the gold that the ESF sought) a price per ounce that would match or exceed the amount they could collect by selling the gold to the U.S. Assay Office in New York, so there would be nothing to gain from shipping gold to New York. The gold would remain in London. The Treasury's initial motive was to deter gold shipments to New York, but over time, the motive changed: its London gold purchases stabilized the dollar-sterling exchange rate. 


\subsection{The Tripartite Agreement}

After protracted negotiations over a period of months conducted by Secretary Morgenthau (through intermediaries in Washington and Paris) with British Chancellor of the Exchequer Neville Chamberlain and French Minister of Finance Vincent Auriol, to draft a common declaration, the British, French and Americans finally agreed on a text that each country issued on 25 September 1936, pledging to cooperate in stabilizing international economic relations. ${ }^{10}$ The agreement was between governments, not central banks, although central banks were clearly crucial in fixing the technical arrangements.

On October 1st French legislation authorized devaluation of the franc between 25.19 and 34.35 percent of the old gold parity. The Banque de France was authorized to revalue the gold stock at the upper of these limits. The law also authorized the creation of an exchange stabilization fund, to which 10 billion of the 17 billion franc devaluation profit was assigned.

Following the French announcement, the British and the Americans stated their support for the French decision. The government statements of intent became effective in October and November with a series of bilateral agreements. A new international gold settlements system was thereupon established, including sterling, the French franc, the dollar, the belga, the Swiss franc, and the guilder. ${ }^{11}$

The secretary of the Treasury sent a letter to the President on 27 September requesting authority to purchase gold through the ESF by the use of dollars, foreign exchange or other obligations, currency or securities, from all or any foreign governments, foreign central banks or the Bank of International Settlements. The President approved the request the same day.

In addition, the powers of the FRBNY under the policy of 31 January 1934 were modified to conform to the arrangements under the Tripartite Agreement. As fiscal agent of the ESF, the FRBNY negotiated details of the operation of the Tripartite Agreement with the Bank of England and the Banque de France. Each central bank would convert into gold the balances in its own currency accumulated each

\footnotetext{
${ }^{10}$ The text of the American declaration is available on reel 9, Book 33, 258-60 of the Morgenthau Papers.

${ }^{11}$ The other countries in the gold bloc also adjusted their exchange rates. The Swiss franc was devalued. The Netherlands Bank did not devalue the guilder but allowed it to depreciate 20 per cent in dollars and maintained it at that level. The Belgians had devalued the franc by 28 per cent on 31 March 1935 and renamed it the belga, and returned to the gold standard at the lower parity in March 1936.
} 
day by the other central bank as a result of its foreign exchange dealings, and release from earmark the gold that would match the obligations incurred by the foreign central bank.

The central banks also agreed to notify each other each day of transactions as a result of which gold was to be earmarked or released. Since the gold value of the franc fluctuated within stipulated limits and there was no official gold price of sterling at all, both the Banque de France and the Bank of England agreed to quote buying and selling prices for gold to the FRBNY that would hold for each day for the settlement of transactions. Only the United States had a fixed buying price for an ounce of gold: $\$ 35$ less $\frac{1}{4}$ of one percent handling charge.

\subsubsection{Operational Features of the Tripartite Agreement ${ }^{12}$}

Two separate accounts were instituted, first by the three original central bank members, and then by the central banks of three additional central bank members. One account was for currency (labeled Control Account 3), and one for gold (labeled Control Account B), through which the transactions of the stabilization funds would be recorded. The ESF operated under the Tripartite system from September 1936 until the outbreak of the war.

Following the French devaluation, sterling declined from $\$ 5.03$ in September 1936 to $\$ 4.89$ in October. What follows typifies ESF operations under Tripartite. The ESF provided some support for sterling during this interval. It bought $\$ 2.25$ million at rates from $\$ 4.96$ to $\$ 4.89 \frac{1}{2}$. Under the standing offer, it bought $\$ 1$ million in gold at $\$ 34.77$. On 12 October it held $\$ 10.83$ million in sterling and $\$ 13.76$ million in gold under earmark at the Bank of England. The motive for the sterling and gold purchases was to keep sterling within a narrow band around $\$ 4.89$ (Sayers 1976, p.481). According to Sayers (1976, p.488), the EEA operated "to funnel dollars to continental buyers." By 1936-7 fluctuations in exchange rates had "retreated" in all ordinary weeks "almost to the range of the old gold points." The ESF was not a passive observer of a less volatile dollar-sterling exchange rate. It was actively engaged in maintaining that stability. 
The principal means the ESF used to stabilize the foreign exchanges was earmarked gold or gold released from earmark under the twenty-four hour rule. These transactions were recorded in the new control accounts established with each participating central bank on behalf of their respective governments or exchange funds. The ESF, however, did not take open positions in foreign currencies, as it previously had sometimes done in francs and sterling.

The Tripartite operated virtually continuously until the outbreak of war in September 1939. It was generally successful in stabilizing the dollar and sterling franc exchange rates ${ }^{13}$. As war approached in September 1939, the Bank of England cabled the FRBNY that it would no longer submit its daily gold price. On 6 September the Treasury was informed of the transfer of the Bank's gold to the EEA. On 12 September the ESF was authorized to sell $£ 8000$ sterling at the wartime rate of $\$ 4.035 / 8$. On that day the Bank closed its Control Account 3 at the FRBNY.

The Banque de France, once sterling was allowed to depreciate, became a seller of francs in New York at rates that declined to 2.31 cents on 6 September. On 8-9 September, the last of these transactions for the account of the Bank were sales of 31 million francs at $2.271 / 4$ to $2.285 / 8$ cents.

On 8 September the ESF bought francs for its own account for the first time in two years. It instructed the FRBNY to transfer them to the Banque de France to be converted into gold along with the small balance in its Control Account 3, and to place the gold under earmark. The ESF closed its Control Account B.

On 9 September the FRBNY did not receive its daily cable from the Banque de France fixing the French gold price. The Treasury was informed when it phoned Paris that the French government had set up a system of exchange controls.

Thus the Tripartite Agreement expired on the outbreak of World War II. Free exchange markets were replaced by measures of exchange controls. Convertibility of the dollar and other currencies ended.

\footnotetext{
${ }^{12}$ In this paper we discuss ESF operations only in sterling and the franc to save on space. The ESF also engaged in considerable intervention in the belga, guilder and Swiss franc markets (the other participants in the Tripartite Agreement). These are described in Bordo, Humpage and Schwartz (2006a) chapter 2.

${ }^{13}$ For details on this intervention see Bordo, Humpage and Schwartz (2006a) .
} 


\subsection{ESF Intervention, 1940-61.}

The years 1934-39 were the zenith of ESF's intervention activities over the entire period 1934-61. During the war the ESF held Swiss francs and balances in foreign currencies in depositories abroad. It made the Swiss francs "available for government and humanitarian purposes," according to the Treasury's statement (Treasury AR 1945, p.95). Little official intervention occurred in the years after the war ended. Most foreign currencies were inconvertible. In addition, the U.S. stock of gold reserves was ample, the U.S. balance of payments was in surplus, and there was an excess demand for dollars in the world.

The U.S. Bretton Woods Agreement Act (PL. 171, $79^{\text {th }}$ Cong.) of 31 July 1945 made a great change with long-term effects on ESF operations. Before that date, the ESF may not have had access to the bulk of the funds that the Gold Reserve Act had set aside for it, but they were a prospective resource. After that date, ESF resources were permanently limited.

The change was the consequence of the provision in section 7 of the Agreement that amended the Gold Reserve Act. The amendment directed the Secretary of the Treasury to use $\$ 1.8$ billion of the ESF capital (shown on the balance sheet as cash in the form of gold held by the U.S. Treasurer) to pay part of the $\$ 2,750$ million U.S. subscription to the IMF.

From 1946 until 1961, the ESF held no foreign exchange of the industrialized countries. A role for an exchange stabilization fund would seem to have been obviated, since the IMF was in place to manage exchange rates, but the ESF regarded the IMF as needing its support.

The conditions that prevailed when the war ended were markedly different from the 1950s on. The economies of Western Europe had recovered, world trade had grown, and demand for U.S. goods and services, and dollars to pay for them became less pronounced. By 1958 the currencies of most of these countries achieved convertibility on current account.

By January 1961, when the Kennedy administration took office, the U.S. balance of payments as measured by outflows of gold and dollars to countries in surplus had substantially deteriorated, The loss of gold to foreigners in that month was seen as an expression of a lack of confidence in the 
administration's commitment to a dollar convertible into gold at a fixed price. The twin goals became to eliminate the balance-of-payments deficit and to check speculation against the dollar. The first goal was elusive. To achieve the second goal, the Treasury wanted to be in the same position as other countries that influenced the exchange rate of their currencies. That required resources to buy and sell other currencies or, in official parlance, sales and purchases of dollars.

To that end the ESF began to operate directly in the foreign exchange market. By June 1961 it had bought spot \$25.4 million sterling and \$20 million D-marks, and \$65 million Swiss francs to counter threats against the dollar.

Even these limited operations strained the resources of the ESF. In June 1961 it had \$200 million in capital plus \$136 million in net earnings accumulated over its twenty-seven year life. Average annual net earnings approximated $\$ 5$ million, from income on gold bullion sales, gold and exchange transactions and its U.S. government securities portfolio. To finance its foreign exchange purchases of roughly $\$ 100$ million in 1961, the ESF had reduced its account at the FRBNY by $\$ 1$ million and sold U.S. government securities (Schwartz 1997, p.144).

In this environment the Treasury persuaded the Federal Reserve to serve as its partner in exchange market intervention. So began the second period of ESF intervention operations.

\subsection{Objectives of ESF Intervention and Were They Successful?}

The initial motive for intervention was to imitate the British invention of the EEA, believed by the Roosevelt administration to be depressing the exchange value of sterling at the expense of American foreign trade. By contrast, the attitude to currencies of gold standard countries was supportive, selling them gold and buying their currencies when weak, providing them with dollars when needed.

Neither before nor after the Tripartite Agreement was the fact of misalignment of currencies recognized as the basic problem that needed correction. Morgenthau hailed the Agreement because it emphasized cooperation among the adherents. No effort was made in the flurry of Tripartite intervention to address the fundamental exchange rate problem, revealed by differences in government spending, taxes, labor market policies, and in domestic price movements of the countries involved. The Tripartite 
was not a solution since it simply preserved the pre-existing misalignment that devaluation of the gold bloc currencies did not cure. Intervention by the ESF, even if it alleviated an immediate problem affecting the currencies it dealt with, did not contribute to improved economic or trade expansion.

\section{Section 4: Bretton Woods and Federal Reserve Swaps ${ }^{14}$}

\subsection{Background}

The officials who signed the International Monetary Fund (IMF) Articles of Agreement at Bretton Woods, New Hampshire, in July 1944, envisioned an international financial system based on close cooperation, which would foster stability, promote economic growth, and prevent a return to the beggar-thy-neighbor policies of the 1930s. ${ }^{15}$ Under the agreement, the United States pegged the dollar to gold at $\$ 35$ per ounce and pledged to buy and sell the metal freely at this price. Other nations established parities for their currencies relative to the dollar, which required them to defend their exchange rates through interventions, restraints on transactions, and-ultimately—-the adoption of compatible monetary policies.

The Bretton Woods system failed for two reasons. Triffin (1960) described the first in his famous paradox: At \$35 per ounce, the official gold price was too low to induce sufficient gold production (see Bordo 1993, James 1996). The United States, however, provided needed liquidity by running persistent balance-of-payments deficits. In the early 1960s, total external dollar liabilities began to exceed the U.S. gold stock, implying that the United States could not completely fulfill its pledge to sell gold at the official price (see figure 4). The situation created uncertainty about the long-term viability of the Bretton Woods parity structure. The second problem underlying the unraveling of Bretton Woods was an unacceptable rise in U.S. inflation beginning in 1965. This exacerbated Triffin's paradox by forcing other

\footnotetext{
${ }^{14}$ The views expressed in this article are those of the authors and not necessarily those of the Board of Governors of the Federal Reserve System, the Federal Reserve Bank of New York, or the Federal Reserve Bank of Cleveland. ${ }^{15}$ For useful background information: See Meltzer (1991), Bordo (1993), and James (1996). Pauls (1990), Todd (1992), and Hetzel (1996) discuss U.S. exchange-market policies during the Bretton Woods era. Beginning in September 1962, the Special Manager for foreign-exchange operations began issuing regular reports, which provide a running account of U.S. exchange-market developments and foreign-exchange operations (see Bulletin, various issues).
} 
countries to hold even more dollars. Once President Nixon closed the gold window in 1971, foreign nations that were unwilling to inflate along with the United States either could impose costly and disruptive restraints on international transactions or float their currencies. In March 1973, they generally chose the latter.

Figure 4: U.S. Gold Stock and External Liabilities

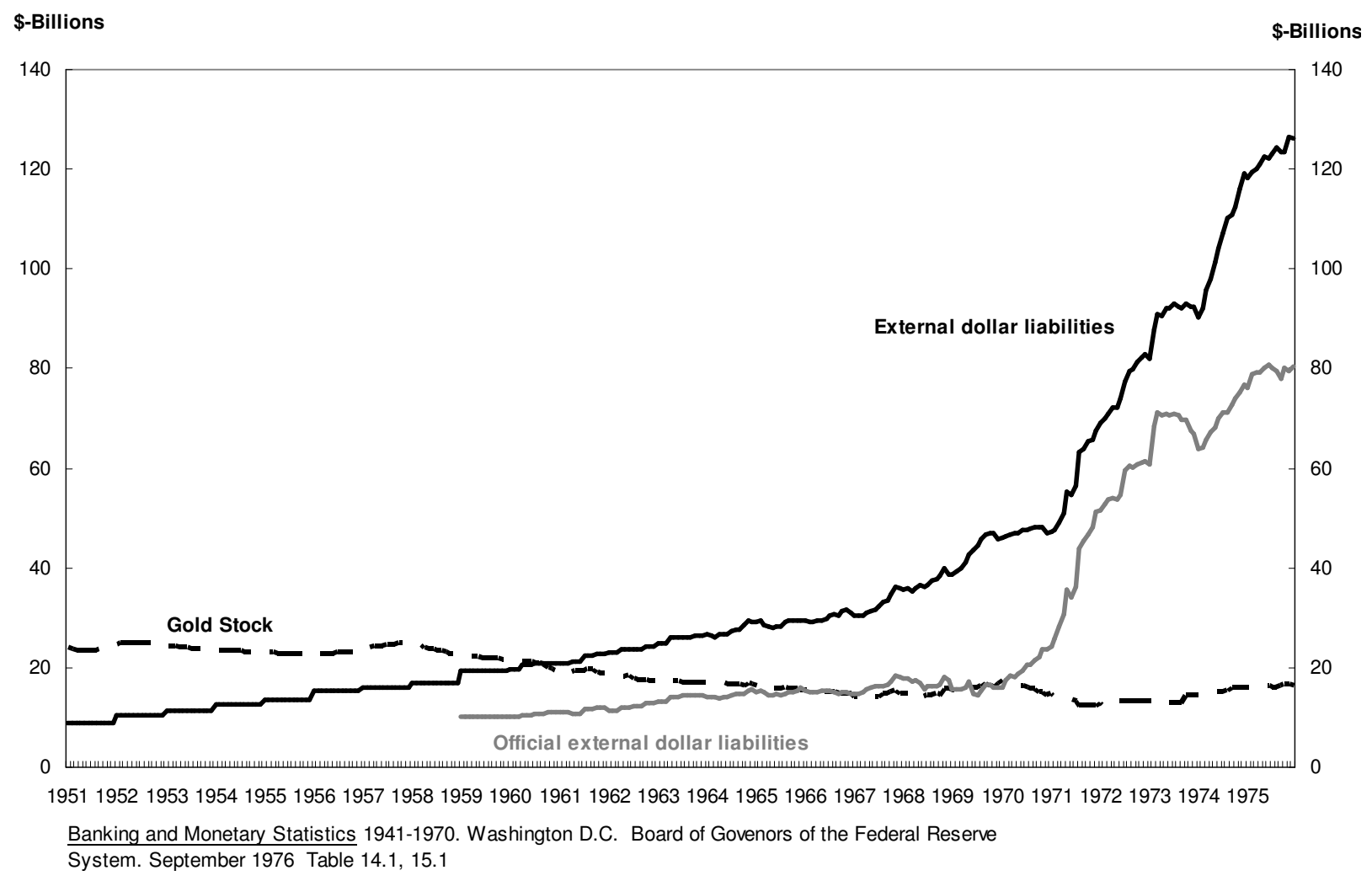

Complicating these two fundamental problems of the Bretton Woods era were shortcomings associated with the adjustment of cross rates within the system. Great Britain, for example, ran persistent balance-of-payments deficits, implying an overvalued exchange rate, while Germany experienced the opposite. Cross-rate adjustment problems stemmed from economic developments within specific countries and not directly from the persistent U.S. balance-of-payments deficits. Nevertheless, these adjustment problems contributed to the dollar's difficulties in two ways: First, they created uncertainty about the entire Bretton Woods parity structure. If Britain, for example, devalued the pound, how might 
other countries, like France, the Netherlands, or Belgium respond, and what would the resulting series of events do to the entire system? Second, uncertainty about cross rates often induced speculative flows from deficit countries to surplus countries, which passed through dollars— the key vehicle currency—and added to the large, often unwanted dollar positions of surplus countries. As discussed below, such developments often compelled U.S. intervention.

When the shortcomings of the Bretton Woods system first started to appear in the late 1950s and early 1960s, U.S. policy makers did not seem to interpret them as evidence that the dollar was fundamentally overvalued in real terms. If they did, they were unwilling to make the appropriate policy adjustments. A nominal devaluation was out of the question, because it would threaten the reservecurrency status of the dollar. Similarly, throughout the entire period, U.S. policy makers generally were unwilling to risk growth and employment objectives for balance-of-payments purposes. They seemed to hope that surplus countries would bear the adjustment costs. Instead of a fundamental policy change, U.S. monetary authorities adopted a series of stop-gap initiatives, one of which was foreign-exchangemarket intervention.

The U.S. Treasury began intervening for the first time since World War II in March 1961, after Germany and the Netherlands revalued their currencies. Even though the speculative surge that resulted from these revaluations did not directly target the dollar, the massive reshuffling of funds resulted in heavy concentrations of dollars in continental European central banks. U.S. authorities feared that these banks might convert them into gold. In its intervention operations, the Treasury generally bought dollars forward, thereby covering foreign-held spot positions.

Both the Treasury and the Federal Reserve System viewed these intervention operations as successes. The Treasury had acted against short-term speculative movements of funds and had easilyand profitably — unwound the positions when speculative pressures abated. With the Treasury's encouragement and after a lengthy debate about the legal authority for such operations, the Federal Open 
Market Committee authorized interventions for the System's own account on February 13, 1962 (see Bordo, Humpage, and Schwartz (2006b)). ${ }^{16}$

Although the Federal Reserve shared the Treasury's same broad policy goals of bolstering confidence in the dollar and forestalling further gold losses, its day-to-day operational objectives were distinctly different. For both political and economic reasons, the FOMC favored only temporary interventions aimed at transitional market disruptions. The System did not want to hinder fundamental market adjustments to balance-of-payments problems or to interfere with the normal pricing operations of private market makers. ${ }^{17}$ Longer-term operations fell to the U.S. Treasury, which had a clearer legal mandate for intervention. As would become apparent, distinguishing between temporary disruptions and fundamental disequilibrium was difficult (see Board of Governors, Treasury Views, 1968).

\subsection{Swaps, et al.}

Following the FOMC's authorization, the System established a series of Reciprocal Currency Arrangements or formal swap lines. ${ }^{18}$ Swaps are standard foreign-exchange-market transactions in which parties simultaneously undertake spot and offsetting forward transactions at agreed prices and settlement dates. Swaps offered a means of financing interventions. At the time, with central banks acquiring unwanted dollar balances and with frequent downward pressure on the dollar, the System could not quickly acquire sufficient foreign-exchange reserves through outright purchases in the market or from central banks, because this would only supply additional dollars to the market and central banks. Moreover, given the underlying problem of forestalling gold losses, the System might need to undertake interventions involving many currencies. A large net open position in a broad array of currencies, however, exposed the System to valuation losses and potentially to Congressional acrimony. As

\footnotetext{
${ }^{16}$ The Federal Reserve routinely reports on its foreign-exchange operations, and in 1980, Congress amended section 14(B)(1) of the Federal Reserve Act to allow the System to invest foreign currencies in short-term foreign government securities, implying tacit Congressional approval of the Federal Reserve's foreign-exchange operations. ${ }^{17}$ See the FOMC Minutes for the September 12, 1961, December 5, 1961, and January 23, 1962, meetings. See also Hetzel (1996).

${ }^{18}$ The U.S. Treasury also used swaps during the Bretton Woods period, but their swap arrangements typically were ad hoc in nature or established to provide temporary loans to developing countries (see FOMC Task Force Paper $\# 9,1990)$.
} 
explained below, swaps avoided these problems. By the end of 1962, the Federal Reserve System's swap network totaled \$900 million and included nine countries and the Bank for International Settlements (BIS). It grew to $\$ 17.4$ billion by 1973 , reflecting persistent U.S. balance-of-payments deficits (see figure $5) .{ }^{19}$

Figure 5: Federal Reserve Swap Lines

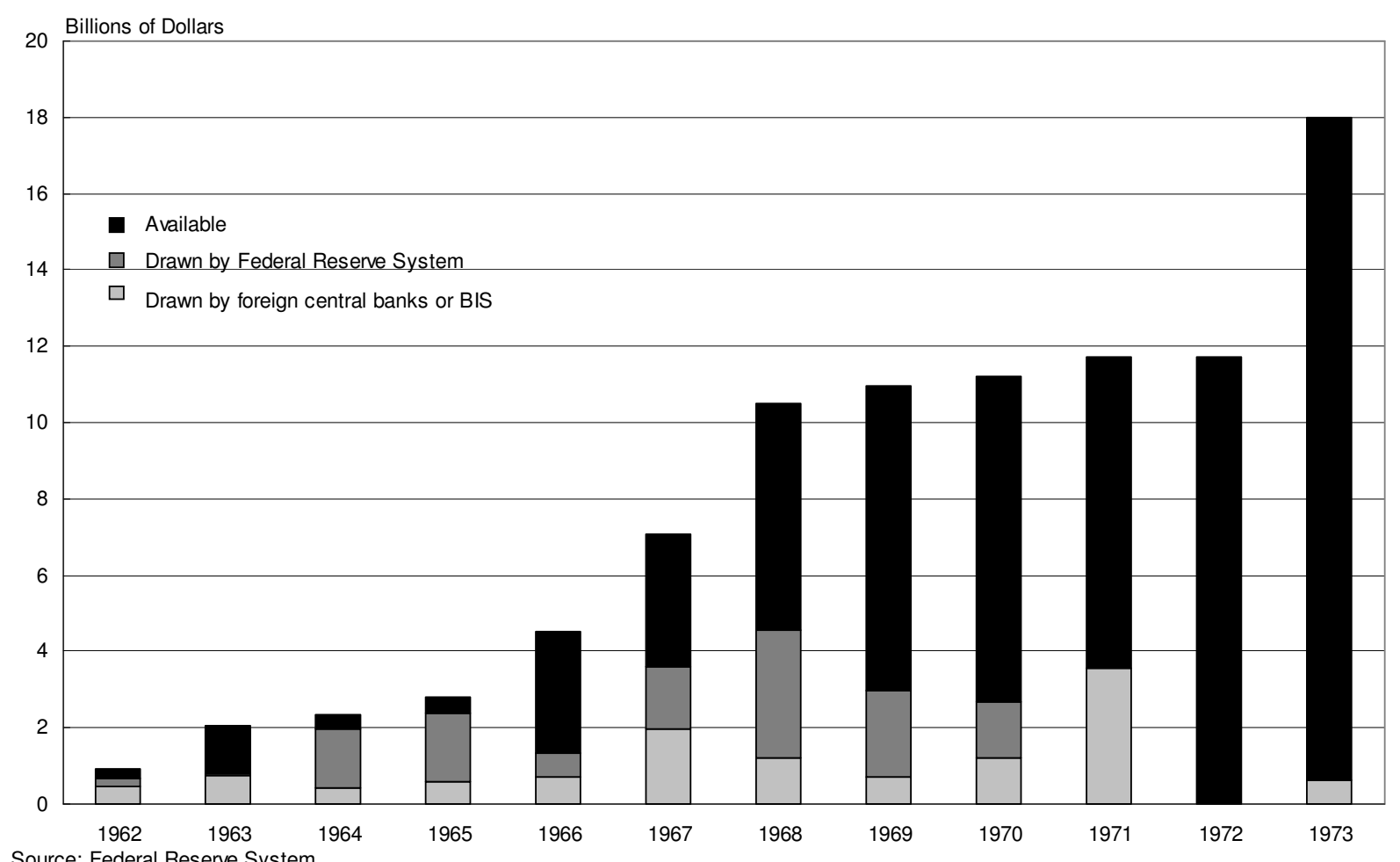

Although swaps were the bulwark of the Federal Reserve's dollar defense, the Federal Reserve and the Treasury sometimes intervened in the spot market, and occasionally undertook outright forward transactions. The Federal Reserve and the Treasury viewed spot intervention as a rather roundabout, ineffective method for preventing gold losses. Moreover, large and persistent spot operations might distort market pricing or actually induce private speculation by signaling official concern about a specific

\footnotetext{
${ }^{19}$ The Bank of Sweden and the Bank of Japan did not join the swap network until January and October 1963, respectively, when their currencies became formally convertible under Article VIII of the IMF Articles. In 1965, the System set up a second swap line with the BIS, and in 1967, Denmark, Norway, and Mexico joined. The FOMC rejected a proposed swap line with Venezuela.
} 
exchange rate. Spot transactions were more suited to the defense of currency pegs vis à vis the dollar, and this responsibility fell to other countries.

Nevertheless, both the System and the Treasury undertook spot transactions during the Bretton Woods era primarily to calm crisis situations that, if left unchecked, might grow to threaten the overall parity structure. A notable example occurred immediately following President Kennedy's assassination on November 22, 1963, when trading in the New York market essentially stopped. To prevent panic selling, which seemed to afflict the stock market at the time, the System placed large orders to sell all major currencies at exchange rates existing just prior to the assassination. By the close of business, the Federal Reserve Bank of New York had sold \$23.5 million equivalent German marks, British pounds, Netherlands guilders, Canadian dollars, and Swiss francs. The System also intervened to stem financial flows during the Cuban missile crisis in October 1962.

In addition, the System undertook some limited—almost experimental—spot transactions of the type that would become standard after Bretton Woods collapsed. Between 1962 and 1968, for example, the System occasionally sold German marks spot to moderate upward movements in the mark and to reduce expectations of a revaluation. In September 1963, the System bought British pounds in concert with other central banks to reinforce an appreciation of the pound at that time. During 1963, the System also undertook a series of interventions in the Paris market, which unsuccessfully attempted to depreciate the franc. For the reasons already mentioned, these were rather limited operations until after President Nixon closed the gold window in August 1971 and, especially, until the onset of generalized floating in March 1973.

Likewise the System and the Treasury occasionally undertook outright forward transactions during Bretton Woods. These had three attractive attributes: They conserved scarce foreign exchange. They operated on forward premiums—-barometers of market sentiment about the long-term viability of fixed spot rates. They offered cover for privately held dollar exposures, which otherwise might be offloaded to foreign central banks and converted into gold. Despite these advantages, forward operationsunlike swaps — could leave monetary authorities carrying exposures for undesirably long periods of time. 
The Federal Reserve System, nevertheless, relied overwhelmingly on the swap mechanism during the Bretton Woods system. Swaps emphasized the temporary nature of the Federal Reserve's intervention operations while also signaling central-bank cooperation to the market. Participants generally negotiated the conditions for the swap lines-the overall limits on the amount and the duration of borrowings — on a twelve-month basis. Most lines were initially established with relatively small— $\$ 50$ million—borrowing limits and three-month maturity dates. Typically, the arrangements allowed for only one rollover, and except for the Belgian swap line, participants were not to draw continuously on the lines. ${ }^{20}$ Once the participating central banks negotiated these conditions, they became reciprocal, meaning that either party could initiate a drawing, and they operated on a standby basis, meaning that drawings were otherwise to be unconditional.

During the Bretton Woods era, central banks typically executed swaps on a flat basis; that is, both the spot and forward exchange rates were the same, as were any interest rates on investment vehicles associated with the drawings. In a typical swap transaction, the creditor central bank would invest its foreign-exchange proceeds in an interest-earning instrument for the duration of the swap. The country initiating the swap would usually finance an intervention with the proceeds, but might also have sought to invest any unused portion of the drawing temporarily. If, for some reason, similar-yielding investment vehicles were not available, deviations between the spot and forward exchange rates could compensate one of the parties. No party to a swap, however, was to earn a profit directly from the transaction.

While the swaps themselves were neutral with respect to returns, a profit or loss could result from the associated intervention, since under Bretton Woods, spot rates could still deviate within a $1 \%$ band around their central parity. (Intervention points were typically narrower.) The party initiating a drawing for intervention purposes was especially vulnerable should the creditor country revalue its currency. To avoid this risk, swap lines during the Bretton Woods era included "revaluation clauses." Accordingly, creditor countries agreed to sell to the country that initiated the swap a sufficient amount of its currency at the initial exchange rate to repay the swap without a loss. The clause was only used once, when the

\footnotetext{
${ }^{20}$ As time passed, the definition of what constituted temporary would become problematic (Board of Governors, Treasury Views, 1968).
} 
Netherlands Bank allowed the guilder to float in early May 1971 (FOMC, Task Force Paper \#9, 1990, p.5). Sometimes the creditor country instead gave the borrowing country a two-day notice of a revaluation, enabling the borrowing country to buy currency in the market. Revaluation clauses, however, provided no protection against a change in the entire exchange-rate system. The System incurred losses amounting to nearly $\$ 1$ billion on swaps with the Belgian National Bank, the Bank of England, the Bundesbank, and the Swiss National Bank following the closing of the U.S. gold window and the subsequent floating of dollar exchange rates (FOMC, Task Force Paper \#9, 1990, p. 5, and FOMC Task Force Paper \#10, 1990, p. 25). ${ }^{21}$

Swap lines generally provided a mechanism for financing an intervention, including drawings to provide cover for a central bank's position and to finance a market transaction. Swap drawings that provided cover were especially important to the Federal Reserve. The Swiss franc market provides an example of this common type of operation. During the first half of 1962, the Swiss National Bank (SNB) accumulated a large, unwanted dollar exposure from defending its peg, as speculative and safe-haven funds moved out of U.S. dollars, British pounds, and Canadian dollars—currencies then under downward pressure. To preclude the SNB from selling its excess dollars for gold—an event that, given Triffin's paradox, would only encourage other central banks to do likewise- the System swapped $\$ 50$ million for Swiss francs with the SNB and $\$ 60$ million for Swiss francs with the BIS on July 16, 1962. (The U.S. Treasury undertook outright forward sales of francs and sold franc-denominated securities to the SNB.) The System then used the Swiss franc proceeds from these drawings to buy dollars from the SNB. Although the SNB continued to hold the same amount of dollars as before the swap drawing, the forward leg of the swap now covered the bank's position. Transactions like this were very common during the Bretton Woods era up to the closing of the U.S. gold window on August 15, 1971.

Nevertheless, foreign central banks relied heavily on swap drawings during the Bretton Woods era to supplement reserves when their currencies were under downward pressure. Between 1962 and 1973, the United States drew nearly $\$ 12.2$ billion equivalent of foreign exchange from the swap lines,

\footnotetext{
${ }^{21}$ Measuring profits and losses on foreign-exchange operations is very difficult because the results depend on how one treats opportunity costs. The FOMC Task Force Paper \#10, 1990 (pp. 24-27) contains a lengthy discussion of
} 
whereas foreign central banks drew $\$ 13.0$ billion (see figure 5). ${ }^{22}$ Typically, the pressure that prompted foreign central banks to draw on their swap lines did not stem from a lack of confidence in the dollar but from the aforementioned cross-rate-adjustment problems within the Bretton Woods system. Although many countries initiated such drawings, the United Kingdom accounted for two-thirds of all foreign swap drawings between 1962 and 1973 (see figure 6). In contrast, the swap lines with Mexico, Norway, and Sweden were never used during the Bretton Woods era.

Figure 6: Composition of Swap Drawings
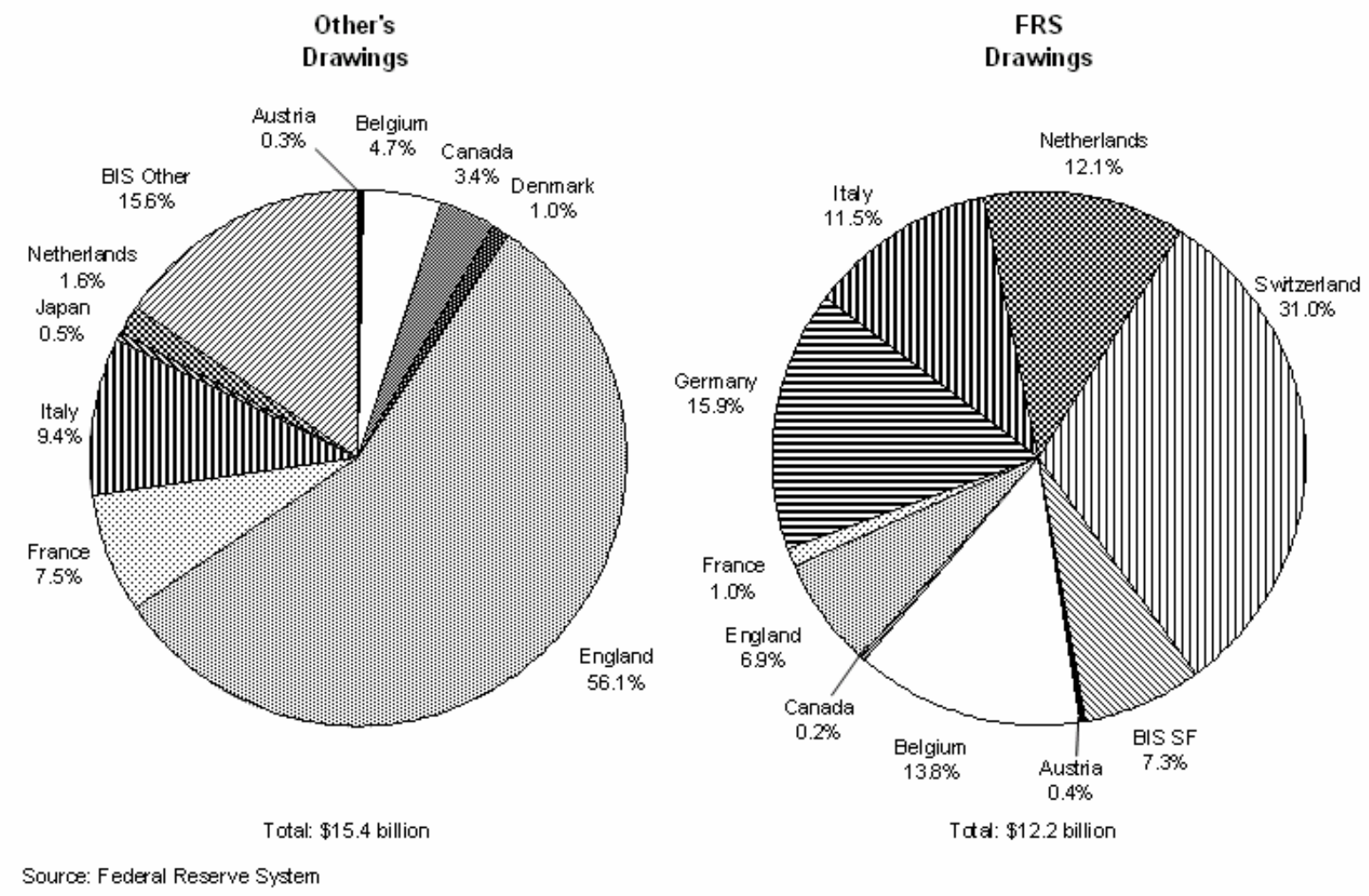

After President Nixon closed the gold window, the Federal Reserve no longer needed to forestall gold losses through swap operations. U.S. monetary authorities suspended their intervention operations this issue as it pertains to the collapse of Bretton Woods. See also Leahy (1995). 
until July 1972. Thereafter, however, the System, which had a limited portfolio of foreign exchange, relied on swap lines to finance spot dollar defenses. The swap lines grew substantially in July 1973.

In addition to financing intervention, swap lines may have affected speculative financial flows during Bretton Woods by increasing the perceived costs of taking and holding open positions. An increase in a swap line—-because it temporarily augmented a central bank's reserves—enabled that bank to withstand a speculative attack longer. Swaps thereby could increase the perceived costs of financing a speculative position in a specific currency. Often during the Bretton Woods period, the mere announcement of a new credit facility or the expansion of an existing one seemed to stem speculative activity. The System may have had this effect in mind when it broadened and extended its swap lines, particularly after 1965 , because after that date, drawings on the facility fell far short of the total available amounts (see figure 5).

Although swaps lines generally financed foreign-exchange interventions, the System's second line with the BIS — the one not involving Swiss francs—-had two other purposes. First, the BIS often initiated drawings on this line to temporarily finance routine transactions. Second, the System and the BIS sometimes provided liquidity to the Eurodollar market through this swap line. In 1967 and 1968, when high Eurodollar interest rates attracted funds out of foreign currencies—particularly out of British sterling - the BIS drew on this swap line and deposited the dollar proceeds into the Eurodollar market. (The central banks of Germany, the Netherlands, and Switzerland also placed dollars in the Eurodollar market or undertook compatible operations.) These transactions, unlike the Fed's covering operations, increased the U.S. monetary base.

\subsection{Federal Reserve and U.S. Treasury Relations}

Although the Federal Reserve System and the U.S. Treasury often worked in tandem, a clear division of responsibility existed between these agencies during the Bretton Woods period. The Federal Reserve focused on short-term operations, financed through swap drawings. Ideally, the System would

\footnotetext{
${ }^{22}$ This number for foreign drawings does not include those initiated by the BIS on the swap lines denominated in currencies other than the Swiss franc because of the unusual nature of many of these drawings. Including them increases the total to $\$ 15.4$ billion.
} 
soon reverse these transactions, so exchange-rate exposure and exchange loss generally were not big concerns. The U.S. Treasury engaged in similar short-term operations, but because of its clearer authority for intervention, the Treasury also undertook operations of a longer-term nature. Typifying this division of labor, the Treasury stood ready to "backstop" System swap operations when market conditions prevented the Federal Reserve from reversing a swap drawing.

During Bretton Woods, central banks typically did not buy (or sell) foreign currencies if they traded above (or below) their central parity, even if those currencies were well within their $1 \%$ trading bands. Our Swiss franc example illustrates the problem. Between July and early October 1962, pressures on the Swiss franc subsided and afforded the System opportunities to buy sufficient Swiss francs from the SNB to pay down much of its drawing on the BIS swap line, but not to repay any of its swap obligation with the SNB. Initially, the System rolled over its swap drawing with the SNB for an additional three months, hoping that pressures on the Swiss franc would abate. When this did not happen, the System undertook its first third-party swap. The System swapped British pounds for Swiss francs with the BIS and used the francs to repay the SNB. Third-party swaps became fairly common, but they only extinguished one swap obligation by extending another, and they skated close to a violation of the System's admonition against intervention of long duration. To terminate swap obligations when speculative pressures persisted, the System ultimately turned to the U.S. Treasury.

Under their informal agreement, if the Federal Reserve could not reverse a swap borrowing within the acceptable time, the U.S. Treasury would bail the Federal Reserve out of its swap obligation. The Treasury could obtain the necessary foreign exchange either by selling longer-term, foreigncurrency-denominated securities to the Fed's counterparty, by drawing on its credit lines with the IMF, or in very extreme circumstances, by selling gold to the central bank that had extended the swap credit to the System. ${ }^{23}$ The Treasury would then sell the foreign exchange that it obtained through these operations to the Federal Reserve, which could subsequently unwind its swap position.

\footnotetext{
${ }^{23}$ The Treasury also might negotiate an increase in the dollar reserves that a foreign monetary authority might willingly hold (Board of Governors, Treasury Views, 1968).
} 


\subsection{Were They Successful?}

The FOMC authorized swaps as a means of offsetting temporary speculative movements of funds, which otherwise might drain U.S. gold reserves and undermine confidence in the Bretton Woods parity structure. In that regard, they often proved highly successful. They quickly provided temporary cover or financing for intervention; they signaled central bank cooperation and upped the costs of speculation, and they were largely self-financing once the speculative pressures reversed.

The swap lines also may have forestalled the drain on U.S. monetary gold, but they did not prevent it. The United States continued to lose gold at a rapid pace until the closing of the Gold Pool in early 1968 and again between late 1970 and the closing of the gold window in 1971. These gold losses persisted because swaps did not address the fundamental problems of Bretton Woods, Triffin's paradox, and U.S. inflation. U.S. policy makers, of course, never intended swaps to do so. In that regard, however, their temporary successes enabled policy makers to avoid appropriate policy adjustments. Consequently, swaps may have actually prolonged and worsened the ultimate collapse of the system.

\section{Conclusion}

Exchange market intervention policies followed by the U.S. monetary authorities in recent decades were influenced by precedents from the past. Many of the tools of modern policy had been utilized by the Bank of England and other European central banks during the interwar period and even before World War I. However, most of the exchange rate policies followed before the 1930s would be classified as gold policies, implemented to influence the gold points. Direct exchange market intervention was less common. Policies followed by the U.S. Treasury before World War I can also be classified as gold policy. Direct purchases and sales of sterling and other foreign currencies in the 1920s were sporadic and of limited amount. Many of these techniques were adopted by the Exchange Stabilization Fund established in 1934 which in turn was patterned after the British Exchange Equalization Account.

The ESF actively engaged in gold policy and direct purchases and sales of sterling, francs and other currencies from 1934 to 1939 . These policies were applied initially before 1936 to preserve the gold parity of the franc and to maintain the dollar value of sterling, which was not pegged to gold. From 
September 1936 on, the interventions were conducted under the aegis of the Tripartite Agreement in concert with the British authorities to ensure an orderly depreciation by the franc.

Three decades later, in 1962, the Federal Reserve began active intervention alongside the Treasury. The object of policy then was to protect U.S. gold reserves, under the Bretton Woods gold standard, by the creation of a swap network in the currencies of European countries, Japan and Canada. The swaps were not an innovation (see note 18 above). They were a legacy of the loan contracts the ESF offered Latin American countries, beginning with Mexico in 1936 and then offered to other, usually less developed countries. The model contract called for an exchange of the currency of the borrowing country at the current market exchange rate with dollars - pesos for dollars. Pesos were deposited at the Bank of Mexico in the name of the FRBNY. Dollars were credits on the books of the FRBNY in the name of the Bank of Mexico. Other features of the loan contract were not part of the FRB Bretton Woods swaps (see the text of the U.S.-Mexico loan contract in Bordo and Schwartz (2001).

Many of the techniques and policies developed under the gold standard were used again in the subsequent regimes with very different results. In the interwar gold exchange standard and the postwar Bretton Woods era, credibility of commitment to convertibility was weakened by greater importance placed on domestic objectives. This meant that the classical adjustment was deliberately impeded. Intervention operations were successful at the tactical level but did not prevent the gold exchange regime from collapsing under the shocks of the Great Depression - an event largely brought about by the major countries following incorrect and inconsistent policies and the basic misalignment of exchange rates, or the Bretton Woods system from collapsing owing to monetary policies inconsistent with the fundamentals of the regime.

Since the collapse of Bretton Woods the exchange rate regime has changed to a managed float. Although the regime has changed, many of the techniques developed earlier have been adapted to the new environment. 


\section{References:}

Bank of England Archives 1935. Selected items.

Beckhart, Benjamin H. , Smith, James G. and William A. Brown Jr. (1932). The New York Money Market Vol IV: External and Internal Relations. New York, Columbia University Press.

Bloomfield, T. Arthur (1959). Monetary Policy Under the International Gold Standard, 1880-1914. New York Federal Reserve Bank of New York.

Bloomfield, Arthur (1963). Short-Term Capital Movements Under the Pre 1914 Gold Standard. Princeton Studies in International Finance No 11.

Board of Governors of the Federal Reserve System 1934-61 Federal Reserve Bulletin. Washington, D.C.

Board of Governors of the Federal Reserve System (1943). Banking and Monetary Statistics. 2 vols. Washington, D.C.

Board of Governors of the Federal Reserve System. Federal Reserve Bulletin, "Treasury and Federal Reserve Foreign Exchange Operations," (September 1962, March \& September issues, 1962 - 1972, March 1973, July 1973, January 1974). [Referred to in the text as Bulletin].

Board of Governors of the Federal Reserves System. Minutes of Federal Open Market Committee (September 12, 1961) [Referred to in text as FOMC, Minutes September 12, 1961].

Board of Governors of the Federal Reserves System. Minutes of Federal Open Market Committee (December 5, 1961) [Referred to in text as FOMC, Minutes December 5, 1961].

Board of Governors of the Federal Reserves System. Minutes of Federal Open Market Committee (January 23, 1962) [Referred to in text as FOMC, Minutes January 23, 1962].

Board of Governors of the Federal Reserve System (1968). "Treasury Views Concerning its 'Backstopping' of Federal Reserve Swap Arrangements", staff memorandum to the FOMC. (June 3, 1968). [Referred to in text as Board of Governors, Treasury Views 1968].

Bordo, Michael D., Humpage, Owen F. and Anna J. Schwartz (2006a). A History of U.S. Exchange Market Policy . Chapter 2. NBER ( mimeo)

Bordo, Michael D., Humpage, Owen F. and Anna J. Schwartz (2006b). "Bretton Woods and the U.S. Decision to Intervene, 1957 - 1962," Federal Reserve Bank of Cleveland Working Papers (forthcoming).

Bordo, Michael D. and Ronald MacDonald (2005). "Interest Rate Interaction in the Classical Gold Standard; 1880-1914: Was There Monetary Independence?” Journal of Monetary Economics.

Bordo, Michael D. and Anna J. Schwartz (1999). "Under What Circumstances, Past and Present, Have International Rescues of Countries in Financial Distress Been Successful?" Journal of International Money and Finance. Vol 18. No.4 August pp 683-708.

Bordo, Michael D. and Anna J. Schwartz (2001). "From the Exchange Stabilization Fund to the International Monetary Fund.” NBER Working Paper 8100 (January). 
Bordo, Michael D. (1993). "The Bretton Woods International Monetary System: A Historical Overview." in M. Bordo and B. Eichengreen. A Retrospective on the Bretton Woods System, Lesson for International Monetary Reform. Chicago: The University of Chicago Press.

Brown Jr., William A. (1942). “Operations of the Exchange Stabilization Fund, 1934-1939.” Unpublished Draft (July 11).

Brown Jr., William A. (1944). Chapter VI on "Exchange Stabilization Funds" in Ragnar Nurkse International Currency Experience. Geneva: League of Nations.

Chandler, Lester V. (1958). Benjamin Strong, Central Banker. Washington D.C. The Brookings Institution.

Clarke, Stephen V.O. (1967). Central Bank Cooperation 1924-31. New York: Federal Reserve Bank of New York.

Einzig, Paul (1931). International Gold Movements. Second ed. MacMillan.

Federal Open Market Committee, Task Force on System Foreign Currency Operations (1990). Historical Review of Reciprocal Currency Arrangements (The "Swap" Network) for Foreign Exchange Operations. Paper \#9 January 1990. Unpublished. [Referred to in text as FOMC, Task Force Paper \#9, 1990].

Federal Open Market Committee, Task Force on System Foreign Currency Operations (1990). Profits and Losses in U.S. Foreign-Currency Operations. Paper \#10 January 1990. Unpublished. [Referred to in text as FOMC, Task Force Paper \#10, 1990].

Flandreau, Marc and John Komlos (2002). "Core or Periphery? The Credibility if the Austro-Hungarian Currency 1867-1913." Journal of European Economic History.

Hammond, Bray (1957). Banks and Politics in America. Princeton. Princeton University Press.

Hetzel, Robert L. (1996). "Sterilized Foreign-Exchange Intervention: The Fed Debate in the 1960s," Federal Reserve Bank of Richmond, Economic Quarterly 82(2): 21-46.

James, Harold (1996). "International Monetary Cooperation Since Bretton Woods”, Washington, D.C.: International Monetary Fund.

Leahy, Martin (1995). “The Profitability of U.S. Intervention in the Foreign Exchange Markets". Journal of International Money and Finance. 14 (6): 823-844.

Meltzer, Allan H. (1991). "U.S. Policy in the Bretton Woods Era," Federal Reserve Bank of St. Louis Economic Review (May/June) 54-83.

Meltzer, Allan H. (2003). A History of the Federal Reserve Volume 1: 1913-1951. Chicago: University of Chicago Press.

Miller, Adolph C. (1935). "Responsibility for Federal Reserve Policies: 1927-29" American Economic Review. Vol. 26, No. 3 (September) pp. 442-456.

Moggridge, Donald E. (1972). British Monetary Policy 1924-1931: The Norman Conquest of \$4.86. Cambridge: Cambridge University Press. 
Montagu, Samuel. Annual Bullion Letter, 1934-1939. Appendix I.

Morgenthau Jr., Henry. Morgenthau Papers on microfilm (60 reels). Franklin D. Roosevelt Presidential Library and Museum. New York: Hyde Park.

Myers, Margaret G. (1931). The New York Money Market Vol. I Origins and Development. New York, Columbia University Press.

Nurkse, Ragnar (1944). International Currency Experience, except for Chapter VI, by William A. Brown, Jr. Geneva: League of Nations.

Officer, Laurence H. (1996). Between the Dollar-Sterling Gold Points: Exchange Rates, Parity and Market Behavior. Cambridge: Cambridge University Press.

Pauls, Diane B. (1990). U.S. Exchange Rate Policy: Bretton Woods to Present, Federal Reserve Bulletin (November) 891-908.

Redlich, Fritz (1951). The Molding of American Banking: Men and Ideas. New York: Hafner Publishers.

Sayers, Richard S. (1936). Bank of England Operations 1890-1914. London P.S. King and Son ltd.

Sayers, Richard S. (1976). The Bank of England 1891-1944. 2 vols. Cambridge: Cambridge University Press.

Smith, Walter B. (1953). Economic Aspects of the Second Bank of the United States. Cambridge: Harvard University Press.

Todd, Walter F. (1992). "Disorderly Markets: The Law, History, and Economics of the Exchange Stabilization Fund and U.S. Foreign-Exchange Market Intervention,” in George G. Kaufman, ed., Research in Financial Services: Private and Public Policy, Vol. 4. Greenwich, Conn.: JAI Press, 1992.

Triffin, Robert (1960). Gold and the Dollar Crisis. New Haven, Conn.: Yale University Press.

U.S. Treasury Department. Annual Report, 1934-61. Washington, D.C.: Government Printing Office.

Willis, H. Parker and John H. Chapman (1934). The Banking Situation: American Post-war Problems and Developments. New York: Columbia University Press.

Yeager, Leland (1976). International Monetary Relations: Theory, History, Policy. Second Edition. New York: Harper and Row. 